\title{
Potential Role of Insulin Growth-Factor-Binding Protein 2 as Therapeutic Target for Obesity-Related Insulin Resistance
}

\author{
Hatim Boughanem $^{1}{ }^{(}$, Elena M. Yubero-Serrano ${ }^{2,3}{ }^{\circledR}$, José López-Miranda ${ }^{2,3}{ }^{\circledR}$, Francisco J. Tinahones ${ }^{1,3, *}$ \\ and Manuel Macias-Gonzalez 1,3,*(D) \\ 1 Department of Endocrinology and Nutrition, Institute of Biomedical Research Institute in Malaga (IBIMA), \\ Virgen de la Victoria University Hospital, 29010 Málaga, Spain; h.b.boughanem@gmail.com \\ 2 Lipids and Atherosclerosis Unit, Maimonides Institute for Biomedical Research in Cordoba (IMIBIC), \\ Reina Sofia University Hospital, University of Córdoba, 14004 Córdoba, Spain; \\ helese35@hotmail.com (E.M.Y.-S.); md1lomij@uco.es (J.L.-M.) \\ 3 CIBEROBN (CIBER in Physiopathology of Obesity and Nutrition), Instituto de Salud Carlos III, \\ 28029 Madrid, Spain \\ * Correspondence: fjtinahones@hotmail.com (F.J.T.); mmacias.manuel@gmail.com (M.M.-G.); \\ Tel.: +34-951-036-2647 (F.J.T. \& M.M.-G.); Fax: +34-951-924-651 (F.J.T. \& M.M.-G.)
}

check for updates

Citation: Boughanem, H.; Yubero-Serrano, E.M.;

López-Miranda, J.; Tinahones, F.J.;

Macias-Gonzalez, M. Potential Role of Insulin Growth-Factor-Binding Protein 2 as Therapeutic Target for Obesity-Related Insulin Resistance. Int. J. Mol. Sci. 2021, 22, 1133. https://doi.org/10.3390/10.3390/ ijms22031133

Academic Editor: Lucia La Sala

Received: 17 December 2020

Accepted: 21 January 2021

Published: 24 January 2021

Publisher's Note: MDPI stays neutral with regard to jurisdictional claims in published maps and institutional affiliations.

Copyright: (c) 2021 by the authors. Licensee MDPI, Basel, Switzerland. This article is an open access article distributed under the terms and conditions of the Creative Commons Attribution (CC BY) license (https:/ / creativecommons.org/licenses/by/ $4.0 /)$.

\begin{abstract}
Evidence from observational and in vitro studies suggests that insulin growth-factorbinding protein type 2 (IGFBP2) is a promising protein in non-communicable diseases, such as obesity, insulin resistance, metabolic syndrome, or type 2 diabetes. Accordingly, great efforts have been carried out to explore the role of IGFBP2 in obesity state and insulin-related diseases, which it is typically found decreased. However, the physiological pathways have not been explored yet, and the relevance of IGFBP2 as an important pathway integrator of metabolic disorders is still unknown. Here, we review and discuss the molecular structure of IGFBP2 as the first element of regulating the expression of IGFBP2. We highlight an update of the association between low serum IGFBP2 and an increased risk of obesity, type 2 diabetes, metabolic syndrome, and low insulin sensitivity. We hypothesize mechanisms of IGFBP2 on the development of obesity and insulin resistance in an insulin-independent manner, which meant that could be evaluated as a therapeutic target. Finally, we cover the most interesting lifestyle modifications that regulate IGFBP2, since lifestyle factors (diet and/or physical activity) are associated with important variations in serum IGFBP2.
\end{abstract}

Keywords: IGFBP2; obesity; insulin resistance; lifestyle modification; epigenetic

\section{Introduction}

Insulin-like growth factors (IGFs) are growth peptides, that are implicated in mammalian development, growth and cell proliferation and differentiation [1]. IGFs are usually bound to IGF-binding proteins (IGFBPs), and mediate their actions by regulating their bioavailability [2]. There are six well characterized high-affinity IGFBP members, designated IGFBP1 through 6 . The IGFBP family members share similar structure and molecular organization, which is suggestive of similar mechanism of action, whereas they have different modes of regulation and distinct expression patterns [3]. In this wise, IGFBP2 is a key member that participates in different physiological and metabolic processes.

The physiological role of IGFBP2 on metabolic disorders are controversial and less defined, although there is growing evidence for a solid association [4]. Therefore, understanding metabolic regulation of IGFBP2 and its influence on metabolic diseases could provide new insights that can be applied as therapeutic targets. In this review, we highlight the genetic and molecular structure of IGFBP2 to better understand its metabolic function, genetic regulation, as well as physiological role. We provide an update of the association between low serum IGFBP2 and an increased risk of obesity, metabolic syndrome, type 2 diabetes, as well as insulin resistance. We hypothesize mechanisms by which IGFBP2 could 
be implicated in the development of obesity and insulin resistance as well. We finally review the main risk factors that are associated with low serum levels of IGFBP2, since these factors may be considered for the prevention strategies and treatment of obesity-related insulin resistance.

\section{Building the Molecular Structure of IGFBP2}

The human IGFBP2 gene is located in chromosome $2 \mathrm{q} 35$ and has four exons and three introns [5,6]. The combination of exons and introns provides up to five splice variants. However, only the first transcript variant encodes for the functional isoform, that it is usually found to be involved in its main physiological role [7]. The IGFBP2 gene expression is modulated by the interaction of a number of transcription factors at the regulatory elements in the promoter region. The IGFBP2 promoter is located between the position -674 upstream up to the transcription start site (TSS), localized into $113 \pm 2[5,8]$. In 2006, Sato and collaborators, by studying dedifferentiated lung cancer cells, suggested that the structure of the human IGFBP2 promoter can be organized into three elements, represented as the distal (localized between -674 and -314 , which apparently acts as an enhancer element), middle (extends from -314 to -134 , and seems to be an inhibitor/silencer), and proximal regulatory element (extends from -134 to the transcription start site, and apparently acts as a regulator of transcriptional activity). It is worth mentioning that the proximal regulatory element lacks TATA or CAAT boxes and contains high-GC sequences, meaning that this element may participate in epigenetic regulation (Figure 1A) [8].

In human, a wide number of transcription factors can bind to the IGFBP2 promoter and activate its transcription activity in vitro. In 2006, Sato et al. and Grimberg et al. found by analyzing lung cancer cells, that the IGFBP2 promoter has putative binding sites for early growth response protein 1 (EGR1) and transformation-related protein 53 (p53), that are crucial for its transactivation [8,10]. In addition, in small-cell lung cancer cells, Yazawa et al. (2009) demonstrated that neurogenic differentiation (NEUROD)—a helix-loop-helix (HLH) transcription factor-binds to the enhancer box (E-box) sequence, located at the distal element and regulates its activation [11]. Further, Mireuta and colleagues (2010) argued that the proximal regulatory element is a potential target for specificity protein 1 (Sp1) [12]. In 2017, Lee and collaborators showed in MCF-7 epithelial breast tumor cells, that nuclear factor IA (NFIA) binds to the E-box sequence, to potentially enhance IGFBP2 transcription as well [13]. Recently, our group, by studying nuclear extracts from visceral adipose tissue, demonstrated that peroxisome-proliferator activated receptor $\gamma 2$ (PPAR $\gamma 2$ ) (through PPAR $\gamma 2$-retinoid $X$ receptor $\alpha(R X R \alpha)$ heterodimer) physically interacts with the IGFBP2 promoter through PPAR responsive element (PPRE) domain [14].

Accordingly, comparative studies in animal models reveal a large number of metabolic transcription factors that can bind to the igfbp 2 promoter, such as multiple endocrine neoplasia type 1 (MEN1), Sp1, PPAR $\alpha$, CCAAT-enhancer-binding protein $\alpha(\mathrm{C} / \mathrm{EBP} \alpha)$, or hypoxia-inducible factor 1 (HIF1) and nuclear factor kappa B (NFkB) [15]. Therefore, these transcription factors could predict the physiological role of IGFBP2, at least at transcriptional and transductional levels. The fact that the IGFBP2 has PPAR, NEUROD, and NFKB binding sites places it as an important mediator of metabolic and inflammatory processes. Conversely, the notion of the interaction with transcription factors, such as p53, sp1, EGR1, and MEN1, provides an idea of its role in cell cycle, cell proliferation, and growth.

Overall, the IGFBP2 gene encodes for a final mature IGFBP2 protein, that contains 289 amino acid residues of $31.4 \mathrm{kDa}$ of molecular weight. Its structure has three principal domains: the N-terminal, middle region, and the C-terminal domain. The N- and Cterminal domains are conserved regions between the IGFBP family members, whereas the middle region shows high variability. This region, therefore, contributes for a singular identity and specific functions (Figure 1B). 


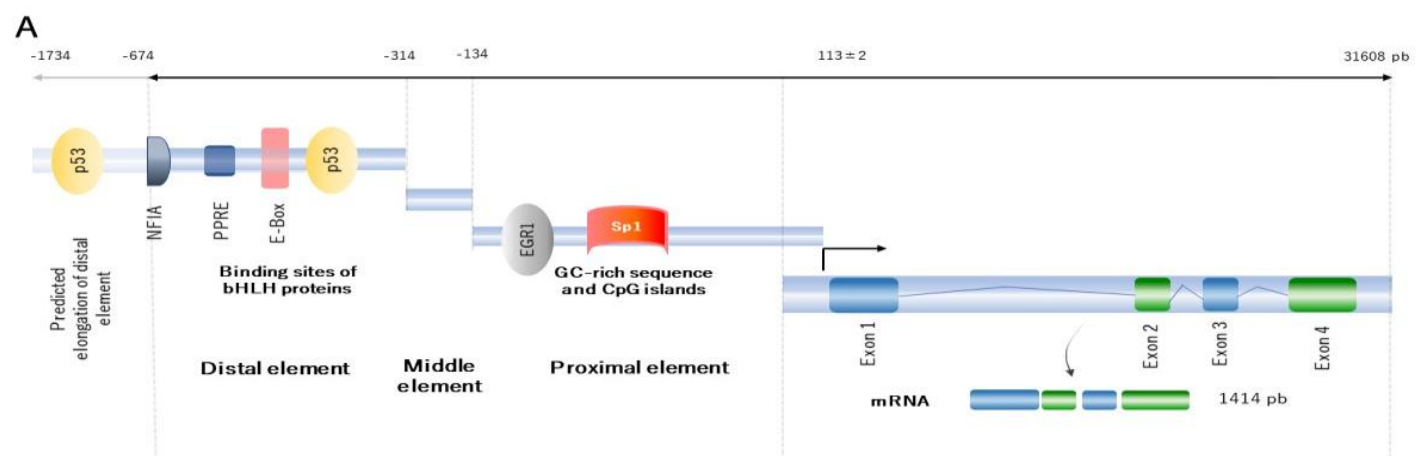

B

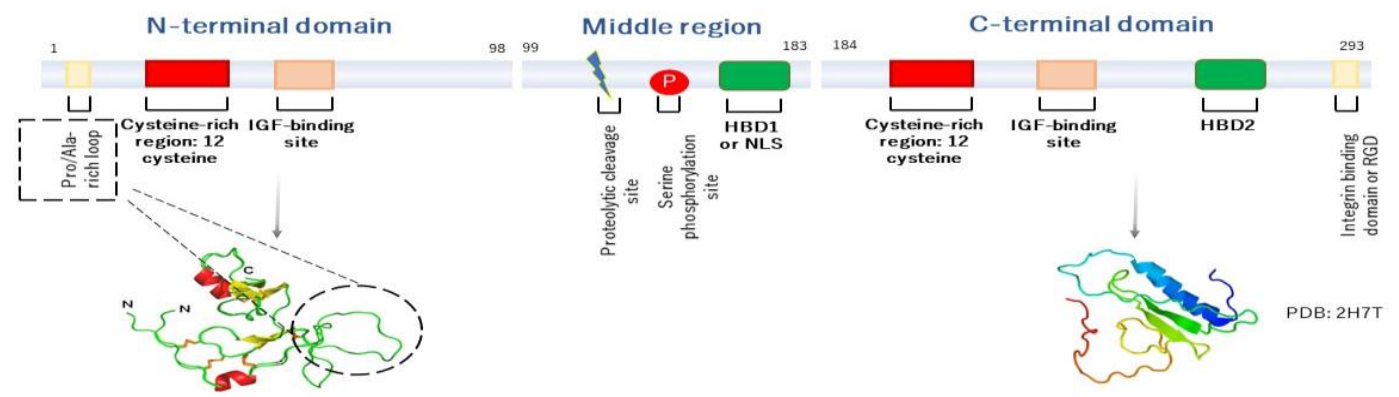

Figure 1. Human representative of IGFBP2 genetic and molecular structure. (A) Human representative of genetic structure of IGFBP2. There are three regulatory elements, ranging from distal, middle to proximal elements. The structure gene contains four exons and three introns. The product is a mature mRNA of $1414 \mathrm{pb}$. (B) Human representative structure of IGFBP2 protein domain for the mature protein of 289 amino acids residues. There are three principal domains. The N-terminal domain, the middle domain or the middle region and the C-terminal domain. The N- (extracted from Galea C. et al. [9]) and C-terminal (PDB: 2H7T for the C-domain of IGFBP2) domain are presented. Both $\mathrm{N}$ - and C-terminal domains contain IGF binding sites, which suggests that these domains are highly conserved. However, the middle region has a proteolytic cleavage and phosphorylation sites, which indicates that this domain may be implicated in the regulation of bioavailability of IGF1 and stability of the protein structure.

The N-terminal domain of IGFBP2 protein, encoded by the exon 1, contains 98 amino acid residues and shares approximately $58 \%$ of sequence between the IGFBP family members. This domain is characterized by containing a highly conserved cysteine-rich region, which allows to form up to six disulphide bonds. The $\mathrm{N}$-domain contains an additional 16-residue Pro/Ala-rich, situated between Pro21 and Arg36 residues, that is not found in the other members. This motif forms a solvent-exposed loop on the three-dimensional structure of the protein, and may comprise a potential -SH3 domain interaction site for binding to other proteins [9]. Within this domain, another local motif (GCGCCxxC) is found, which may be crucial in the interaction of IGFBP2 with IGFs [9]. The N-terminal domain has an IGFs-binding domain, that is involved in high-affinity binding to IGFs [9].

The middle region (called L-domain) is encoded by the exon 2 and links the $\mathrm{N}$ - to the Cterminal domains. This domain extends approximately for 85 amino acids residues, and its sequence appears to be unique and singular among the IGFBP members. It is susceptible to proteolytic cleavage and inactivation of IGFBP2 protein, since specific proteases separate the $\mathrm{N}$ - and C-domains, and decrease the affinity of IGFBP2 by IGFs. The middle region has various predicted phosphorylated sites [16], and it is often phosphorylated in serine at the position 106 [17]. The purpose of phosphorylation is still unknown, but may contribute to the resistance to proteolysis. Within the L-domain, there is another subdomain called heparin-binding domain 1 (HBD1), located between 179 and 184. The principal function of 
the HBD1 domain is to bind to extracellular matrix components (as glycosaminoglycans, integrins, etc.). The HBD1 domain can act as a ligand, by binding to the tyrosine phosphatase $\beta(R P T P \beta)$ receptor [18], and mimic the nuclear localization signal (NLS) to translocate into the nucleus as well [19]. Therefore, this motif is required for specific recognition and interaction binding.

Finally, the C-terminal region is encoded by the exon 3 and 4 and contains 107 amino acid residues. Interestingly, the sequence of this domain shares high similarity with the thyroglobulin-type-I domain [20]. This domain is conserved between IGFBP members and characterized by highly conserved six cysteine residues [21]. The main function of C-domain is involved in high-affinity binding to IGFs, which contains a specific region to bind to IGFs. Within this domain, an RGD (Arg-Gly-Asp) sequence, located on 265 and 267 residues, can bind to integrins [22], and activate many physiological and cell cycle processes, such as cell invasion and proliferation, by inducing $\beta$-catenin and further affecting Wnt signaling [23]. The C-terminal domain contains an HBD motif as well, called HBD2. The interaction of HBD2 to proteoglycans leads to regulate many of cell cycle processes as cell adhesion, proliferation, and migration [24].

Classically, the molecular structure of IGFBP2 is designed to bind to IGFs, but also can act as a ligand, through different domains located within the protein. This fact places IGFBP2 as a versatile molecule that could participate in a wide range of metabolic and cell cycle processes. Nonetheless, despite the aforementioned findings, many of the molecular pathways of IGFBP2 remain unknown. Investigating the molecular pathways of IGFBP2 could help to better understand the role that IGFBP2 plays in metabolic diseases.

\section{Mechanism of Action of IGFBP2 and its Physiological Role}

IGFBP2 acts systematically following two main action models, known as IGF-dependent model (IGFBP2 binds and regulates the bioavailability of IGFs) and IGF-independent model (IGFBP2 acts as a ligand by binding to receptors at the cell surface and to extracellular matrix) (Figure 2) [25]. Likewise, the principal function of IGFBP2 starts with its binding to IGFs (they form a binary complex) and modulates their actions at systemic levels. The colocalization of IGF type 1 or 2 with IGFBP2 has frequently been questioned, suggesting a possible leaning for each one. Interestingly, IGFBP2 has more pronounced affinity for IGF2, up to 10-20-fold greater than IGF1, which may be its primary ligand [26]. The binding of IGFBP2 to IGF1 seems to locally modulate IGF1 signaling, under various conditions [27]. However, as discussed below, the biological meaning of the IGF2/IGFBP2 complex is to increase its affinity by the extracellular matrix [28].

The IGF-dependent model is responsible for the regulation of the phosphatidylinositol 3-kinase (PI3K) / alpha serine/threonine-protein kinase (Akt) signalling pathway. The activation of PI3K/Akt pathway starts with the specific proteolysis and release of IGFBP2 from IGF1 or IGF2 and the binding of IGFs to IGF1 receptor (IGF1R) [29]. The complex IGFs/IGF1R leads to conformational changes in the IGF1R, which auto-phosphorylates their subunits $\beta$. The auto-phosphorylation of the IGF1R causes the activation of PI3K, which further induces the phosphorylation and activation of Akt. The active Akt has a wide number of target genes related with cell cycle and glucose metabolism, such as mechanistic target of rapamycin complex 1 (mTORC1), BCL2 associated agonist of cell death (BAD) and translocation of glucose transporter 4 (GLUT4), and also inhibits a large number of genes, as tuberous sclerosis 1 (TSC1) or glycogen synthase kinase $3 \beta$ (GSK3 $\beta$ ) [30]. On the other hand, the phosphorylated IGF1R can also induce the recruitment of SHC adaptor protein (Shc), growth factor receptor-bound protein 2 (Grb2), Son of Sevenless (SOS), and rat sarcoma (Ras), which leads to stimulate the mitogen activated protein kinase (MAPK) signalling pathway. The MAPK pathway is responsible for growth processes, such as development, cell proliferation, differentiation, and migration, as well as inhibition of apoptosis [31] (Figure 2A). As for the IGF2R, it has been thought that it does not have apparent intracellular signalling activity and it is believed to act as a scavenger receptor for IGF2 [32]. However, a study carried out by Chu et al. (2008), showed that IGF2R in H9c2 
cardiomyoblast cell cultures, activates the protein kinase C (PKC)/calcium/calmodulindependent protein kinase II (CaMKII) signalling pathway, which is dependent on the IGF2R [33]. This may result in GLUT4 translocation to the plasma membrane, characterizing an insulin-independent pathway [34].

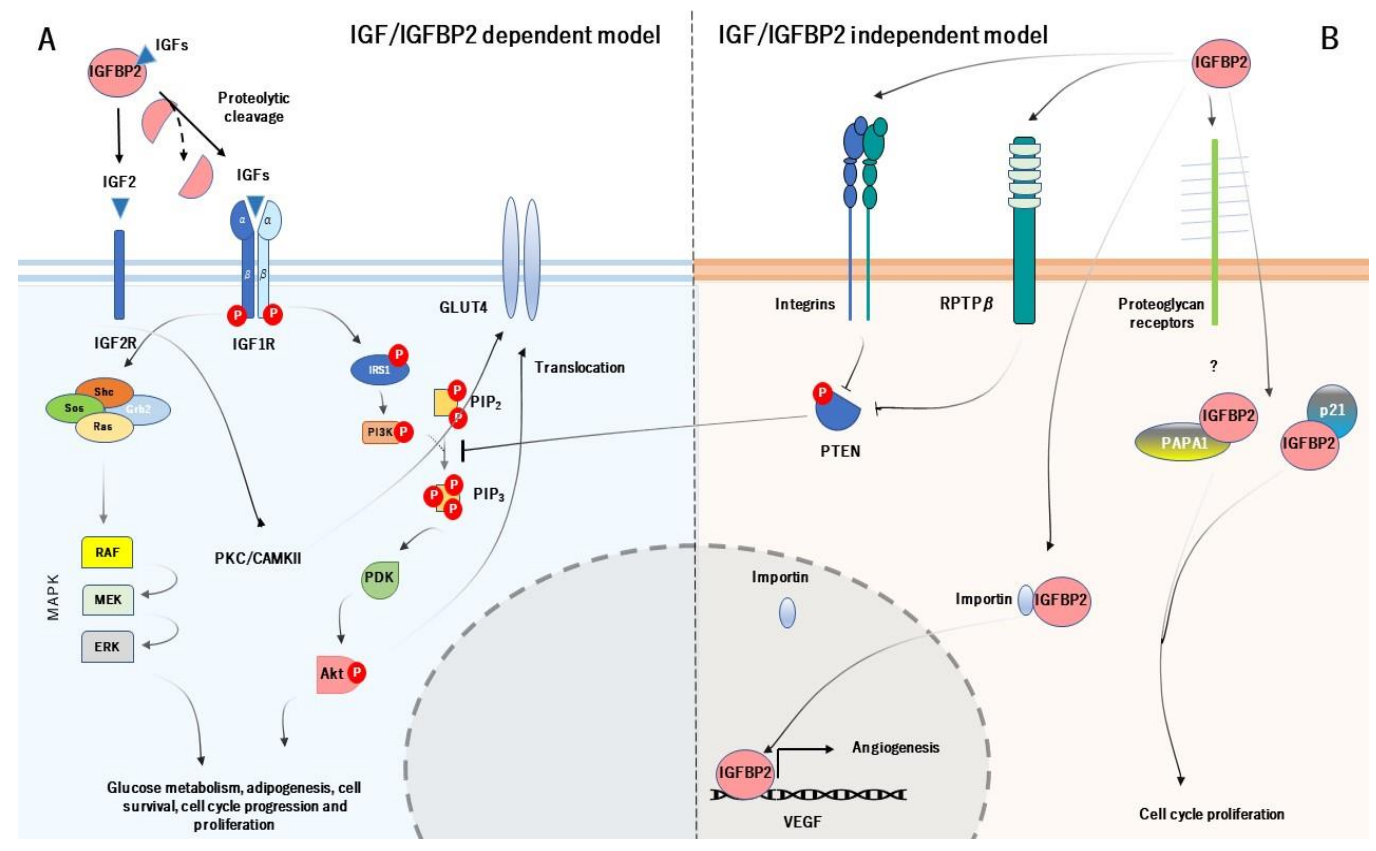

Figure 2. The cellular action of IGFBP2 is mediated by two principal models. The IGF-dependent model (A) modulates the activity and bioavailability of IGFs, which prevents the binding of IGFs to their receptor. The IGF-independent model (B) constitutes the physical interaction between IGFBP2 and specific receptors at the cell surface and extracellular matrix, which acts as a ligand. The main function of both models is regulating cell cycle, insulin, and glucose metabolism and angiogenesis.

As for the IGF-independent model, IGFBP2 acts as a potential ligand that binds to different targets. In particular, IGFBP2 binds to integrins through RGD domain, and stimulates cell migration and proliferation, adhesion, as well as cell differentiation [35]. The activation of IGFBP2/integrin complex increases the phosphorylation and inactivation of phosphatase and tensin homolog (PTEN), which leads to the stimulation of Akt signaling [36] (it is worth noting that despite the IGFBP2/integrin inactivates PTEN, there are also other mechanisms that regulate PTEN in this context). Moreover, IGFBP2 binds to extracellular matrix, which this interaction is mediated by HBD. Its biological function is to modulate the bioavailability of IGFs in the extracellular space and also acts as an active and local reservoir of IGFs to regulate cell adhesion, migration, proliferation, and differentiation $[24,37]$. The HBD domain is used to bind to RPTP $\beta$ receptor, being a receptor with tyrosine phosphatase activity. The IGFBP2/RPTP $\beta$ leads to its dimerization and further inactivates its phosphatase function. The inactivation of RPTP $\beta$, cooperatively with IGF1 triggers to increase the phosphorylation of PTEN and further stimulate Akt [38]. In addition, the binding of IGF2 to IGFBP2 greatly increases the affinity for O-sulfated glycosaminoglycans, heparin, and heparan sulfate. Accordingly, Lund et al. (2014) demonstrated in vitro that the HBD1 and HBD2 contribute differentially to glycosaminoglycans binding and increase the affinity of both free IGFBP2 and the IGF2/IGFBP2 protein complex for heparin [28].

Interestingly, IGFBP2 can be located within the cells as well. A study pointed out that IGFBP2 intracellularly interacts with cyclin-dependent kinase inhibitor 1 (p21), to modulate cell proliferation in vivo in mouse lung epithelial cell line [39]. IGFBP2 also interacts with Pim-1-associated protein-1 (PAPA1) in the human prostate cancer cell line (LNCaP). The binding of IGFBP2 to PAPA1 seems to have a role in growth-promoting effect. The in- 
hibition of PAPA1 enhances cell growth, suggesting that the proliferative effect of IGFBP2 may be regulated by its intracellular interaction with PAPA1 [40]. But IGFBP2 may act at intranuclear levels. A study demonstrated that IGFBP2 can be located into the nucleus in several common cancer cells. This is possible because of the HBD1 motif (HBD1 can mimic the NLS domain). Within the nucleus, IGFBP2 can act as a transcription modulator, which contributes to the activation of the expression of vascular endothelial growth factor (VEGF), an essential gene for angiogenesis [19] (Figure 2B).

As already noted, IGFBP2 modulates the IGF signaling, binds to the extracellular matrix, and interacts with the cell surface receptor to modulate the PI3K/Akt signaling pathway. Given that IGFBP2 regulates the bioavailability of IGFs, it is worth noting that IGFBP2 is a key factor in cell proliferation and growth. The IGFs/IGFBP2 is closely related with glucose/insulin metabolism (through PTEN/Akt signaling) and cell cycle (trough MAPK pathway) as well, which could explain the dual role of IGFBP2 to act in such processes. Thus, the metabolic role of IGFBP2 could place it as a potential regulator in metabolic disorders, either by IGFs/IGFBP2-dependent and independent model.

\section{IGFBP2 and Obesity-Related Insulin Resistance}

IGFBP2 is considered a major regulator of IGFs bioavailability in metabolic signaling pathway. Recent studies show solid association between mRNA and serum IGFBP2 and metabolic disorders, including obesity, metabolic syndrome, insulin resistance, and type 2 diabetes, as detailed below. However, although the mechanisms by which IGFBP2 participates in the development of obesity-related diseases are still controversial, there is more and more evidence for a solid association between serum IGFBP2 and these metabolic disorders.

\subsection{The Suggested Role of IGFBP2 in the Development of Obesity}

The majority of studies reached a consensus idea that serum IGFBP2 is decreased in obesity state, which is observed in different state of obesity and closely related to other anthropometric variables. In 1997, Nam et al. investigated the effect of obesity on the serum levels of IGFBP2 in 88 males. This study concluded that IGFBP2 concentrations were suppressed in 43 obese subjects than in 45 normal controls [41]. Indeed, this effect is manifested at early stages. Both Ballerini et al. (2004) and Yau et al. (2018) analyzed serum IGFBP2 in children with obesity. These studies found that serum IGFBP2 was decreased in obese children [42], and was negatively associated with body mass index (BMI), anthropometric variables, markers of metabolic dysfunction, blood pressure, and insulin sensitivity [43]. Likewise, a prospective study with mean follow-up of 6.2 years, conducted in 2009 by Hu et al. in 625 participants, confirmed the inverse correlation between serum IGFBP2, obesity and adiposity, since higher serum IGFBP2 are associated with lower adiposity and decreased glucose tolerance [44]. Another study conducted in 38 prepubertal obese children, by Claudio and colleagues (2010) showed that IGFBP2 expression in subcutaneous adipose tissue biopsies was associated with fat mass percentage and adiposity, insulin sensitivity, free IGF1 and leptin, suggesting a close relationship between IGFBP2 and adiposity, independently from the level of insulin sensitivity [45].

Furthermore, it is noteworthy to note that IGFBP2 has a protective role in obesity. This evidence was confirmed by a recent study, conducted by Ceccarini et al. (2019) in 51 patients with obesity. These patients had lower IGFBP2 levels compared with 41 lean matched controls. After gastric bypass, serum IGFBP2 increased at 3 days and maintained normal concentrations before the occurrence of relevant changes in body weight, and remained stable up to 18 months after surgery. IGFBP2/leptin ratio also increased early after surgery and return normal after one year [46]. Consistently, a recent study conducted by Al-Regaiey et al. (2020) confirmed the previous findings, showing that serum IGFBP2 increases in 33 obese patients after bariatric surgery and further weight loss [47]. Thus, these studies strongly manifest that IGFBP2 are decreased in obesity state, and suggest that IGFBP2 might be important in the pathogenesis of obesity. These findings point out to pro- 
tective effects, which further in vitro experiments may clarify the physiological mechanism for this protection.

It is worth pointing out that IGFBP2 could prevent obesity through inhibition of adipogenesis according to dependent and independent action models. An in vitro study demonstrated that IGFBP2 prevents adipogenesis, through inhibition of 3T3-L1 cells differentiation and modulation IGF1 activity [48]. It is known that IGF1 mediates adipocyte growth and differentiation, which is known to be increased when preadipocytes differentiate into mature adipocytes. In addition, HBD domains also mediate the inhibitory effect on preadipocyte differentiation [49]. Both HBD1 and HBD2 peptides inhibit preadipocyte differentiation, although the HBD2 peptide is more effective in in vitro and in vivo IGFBP2 ${ }^{-/-}$ mice. The administration of HBD2 to IGFBP2 $2^{-/-}$mice reduced gain in total fat mass and visceral fat accumulation. The HBD2 peptide also increased serum leptin, suggesting that HBD2 domain of IGFBP2 is the primary region that accounts for its ability to inhibit adipogenesis [49]. Indeed, IGFBP2 seems to be more important in visceral adipose tissue than in subcutaneous adipose tissue. Accordingly, a study reported that IGFBP2 DNA methylation is increased in visceral adipose tissue than in subcutaneous adipose tissue in 24 obese subjects, suggesting an epigenetic regulation of IGFBP2 in abdominal obesity [50].

IGFBP2 not only modulates adipogenesis process, but also acts as an adipokine. Hedbacker et al. (2010) showed that leptin-deficient patients $(n=3)$ are associated with decreased serum IGFBP2 in comparison with age- and weight-matched controls. However, after six months with leptin treatment, these patients recovered normal circulating IGFBP2 levels. In addition, the treatment of ob/ob mice with leptin induces the expression of IGFBP2, suggesting a close crosstalk between IGFBP2 and leptin [51]. Leptin is an essential hormone that can regulate adipogenesis, and directly increases the expression of IGFBP2 in human skeletal muscle cells. This effect is carried out by both signal transducer and activator of transcription-3 (STAT3) and PI3K signaling pathways, to enhance insulin signaling. However, when IGFBP2 is silenced, it leads to the decrease of leptin and insulinstimulated protein kinase $\mathrm{B}$ (PKB) phosphorylation as well as glucose uptake. In in vivo experiments, central leptin infusion upregulates the expression of IGFBP2 in skeletal muscle, liver, subcutaneous and visceral fat in sheep infused with intracerebroventricular leptin. This animal model also improves glucose tolerance and serum insulin levels after glucose load. Therefore, leptin regulates IGFBP2, which probably has an impact on peripheral insulin sensitivity and glucose metabolism [52]. Overall, Neumann et al. (2014) showed that IGFBP2 acts as a mediator of leptin on obesity and insulin sensitivity, by restoring metabolic variables and weight/BMI in ob/ob mice in a similar mechanism of action of leptin. However, IGFBP2 alone is not sufficient to mimic the physiological effect of leptin [53].

The action of IGFBP2 in obesity appears to act by both dependent (by modulating IGFs) and independent models (through HBD domains) by directly inhibiting adipogenesis and differentiation of preadipocytes at locally visceral adipose tissue. This action helps to reduce fat mass and weight gain. There is a cross-talk between leptin and IGFBP2. The aforementioned studies suggest that IGFBP2 may be permissive for obesity development, since its role in the pathogenesis of obesity is for long-term. Then, IGFBP2 acts rather as a potential collaborator/mediator of leptin, than a principal actor.

\subsection{The Mechanisms of IGFBP2 in Insulin Sensitivity}

Overall, the abovementioned studies demonstrate that the robust effects of IGFBP2 on obesity are fully reproducible across humans, different animal, and cell line models. The notion that IGF/IGFBP2 system are involved in the insulin system pathway, opens the possibility to think that IGFBP2 might be related to insulin sensitivity. However, many unsolved issues still hinder the role of IGFBP2 in insulin sensitivity and insulin resistance, and the suggested the association with type 2 diabetes, which we discuss below.

Clemmons et al. (1991) reported that serum IGFBP2 did not show significant fluctuation under physiological/metabolic and nutritional conditions, such as post-prandial state 
or administration of glucose. However, a long time of 9 fasting days-as a result of insulin deficiency-caused an increased serum IGFBP2 level in seven obese subjects, suggesting that insulin may have a physiological role in regulating serum levels of IGFBP2 [54]. Arafat and colleagues (2009) demonstrated that insulin increases IGFBP2 in 24 healthy subjects and 19 subjects with impaired glucose tolerance. In addition, subjects with impaired glucose tolerance showed more pronounced insulin resistance and lower serum IGFBP2 levels in comparison with healthy control. IGFBP2 was an independent predictor of insulin sensitivity, which suggests that IGFBP2 plays a central role in the insulin/IGFs system crosstalk and it is closely linked to insulin resistance [55]. In this line, our group (2017) found that both mRNA and IGFBP2 protein in visceral adipose tissue were decreased in 13 morbid obese patients with high insulin resistance when compared with in 12 morbid obese patients with low insulin resistance [56].

Interestingly, in 2018, Yau et al. investigated the relationship between serum IGFBP2 and insulin sensitivity in 194 children with obesity. This study found a positive association between insulin sensitivity index-homeostasis model assessment and serum IGFBP2 [43]. In this line, our group (2019) also determined, by studying nuclear extract from visceral adipose tissue, that the activation of IGFBP2 promoter by PPAR $\gamma 2-\mathrm{RXR} \alpha$ heterodimer was decreased in 11 high insulin resistance patients with morbid obesity, when compared with in 12 low insulin resistance patients [14]. Recently, Van den Beld and colleagues (2019) conducted a 20-year longitudinal study in the Baltimore Longitudinal Study of Aging cohort in 539 participants, where it showed that the serum IGFBP2 was positively correlated with insulin sensitivity and inversely with BMI, both at baseline and follow-up [57].

As noted, these studies demonstrate that is a robust association between IGFBP2 and insulin and glucose tolerance, which indicates that IGFBP2 may regulate insulin sensitivity and glucose metabolism through distinct molecular pathways and/or target organs. Accordingly, in 2012, Li et al. demonstrated in vitro that IGFBP2 mRNA and protein concentration in serum-deprived 3T3-L1 adipocytes were increased by acute insulin treatment. Further treatments with PI3K or mTOR inhibitors blunted the effects of insulin, suggesting that insulin upregulates IGFBP2 expression through a PI3K/mTOR/C/EBP $\alpha$ pathway in white adipocytes [58]. Additionally, Yau and collaborators (2014) reported that leptin directly increases IGFBP2 mRNA and protein in human skeletal muscle cells through PI3K signaling, in parallel with enhanced insulin signaling, and silencing IGFBP2 lowered leptin- and insulin-stimulated PKB phosphorylation and glucose uptake [52]. In addition, in lipoma cells PTEN-deficient, Wilhelm et al. (2015) demonstrated that IGFBP2 production was not influenced, either by inhibition of MTORC1 and MAPK. However, the inhibition of PI3K decreases IGFBP2 expression and secretion [59]. Accordingly, IGFBP2 significantly increases the activation through phosphorylation of PI3K, Akt, AMP-activated protein kinase (AMPK), and PKC in 3T3-L1 adipocytes and induced GLUT4 translocation, improving glucose intake. Moreover, Assefa and colleagues (2017) demonstrated that IGFBP2 stimulates glucose uptake in 3T3-L1 adipocytes through activation of PI3K/Akt, AMPK/TBC1 Domain 1 (TBC1D1), and PI3K/PKC/GLUT4 signaling pathways. IGFBP2 actions were independent of its binding to IGF1 and is possibly not mediated through the insulin or IGF1 receptor [60]. Therefore, all these studies point out that IGFBP2 improves insulin sensitivity through increased glucose uptake and that synergistic activation of PI3K/Akt and AMPK mediates the modulatory effect of IGFBP2 in both dependent and independent actions. It is worth noting that the interaction of IGFBP2 with IGF2 modulates the binding with IGF2 to their receptor. Overall, the activation of IGF2R activates PKC/CAMKII signaling pathway, and further leads to the translocation of GLUT4 and the improvement of glucose uptake $[33,34]$.

\subsection{The Association of IGFBP2 and Type 2 Diabetes}

Regarding the role of IGFBP2 in type 2 diabetes, Rajpathak et al. (2012) found in 742 type 2 diabetes patients and 742 matched control subjects, that IGFBP2 concentration was decreased in type 2 diabetes patients, in comparison with control participants, and higher 
serum IGFBP2 was associated with lower risk of type 2 diabetes [61]. IGFBP2 is not only associated with type 2 diabetes, but also with gestational diabetes. A cross-sectional study, conducted by Lappas and colleagues (2016), found in 98 patients with gestational diabetes mellitus, after adjusting with age and BMI, that serum IGFBP2 was significantly associated with the development of type 2 diabetes [62], indicating that low postpartum IGFBP2 levels are a significant risk factor for the development of type 2 diabetes in women with a previous history of gestational diabetes. In 2017, a study revealed possible mechanism by which higher serum IGFBP2 decreases the risk of developing type 2 diabetes. Further, several longitudinal studies, meta-analyses and systematic reviews confirmed in different cohorts that IGFBP2 is found decreased in type 2 diabetes and supposes a factor risk for development of type 2 diabetes [63,64]. Recently, Wittenbecher et al. (2019) showed that IGFBP2 was associated with lower risk of type 2 diabetes in 755 cases versus 2778 controls, and DNA methylation of the IGFBP2 gene was also associated with higher type 2 diabetes risk, suggesting an epigenetic alteration of the IGFBP2 gene in the type 2 diabetes context [65]. Finally, a recent proteome-wide study, conducted by Noordam et al. (2020) found that IGFBP2 protein was found lower among 175 type 2 diabetes patients compared with 164 controls [66].

As for the IGFBP2 polymorphisms, several studies demonstrated that single nucleotide polymorphisms (SNP) in the IGFBP2 gene are strongly associated with type 2 diabetes. For instance, Horikawa et al. (2008) found that SNP rs1470579 IGFBP2 was associated with significant type 2 diabetes risk in 1900 Japanese patients, with odds ratio (OR) of 1.18 (Confidence interval (CI): 1.07-1.31) [67]. In the same year, another genome-wide study conducted by Cauchi and colleagues, found an increased risk of rs1470579 allele risk and type 2 diabetes in 6890 French population (OR = 1.17; CI: 1.07-1.27) [68]. In 2010, Huang et al. also found a significant association between rs1470579 and an increased risk of type 2 diabetes, and these polymorphisms may affect the therapeutic efficacy of repaglinide in 350 Chinese patients [69]. In contrast, Duesing and collaborators were unable to replicate the confirm rs1470579 susceptibility variant with type 2 diabetes in a case-control cohort comprising 3093 French Caucasian subjects, probably due to the nature of study design [70]. Therefore, there is increasing evidence of the association of polymorphisms of IGFBP2 and type 2 diabetes. However, further genetic and functional studies are needed to clarify the implication of these polymorphisms on the type 2 diabetes contribution.

Therefore, the aforementioned findings suggest that IGFBP2 shares a promising association with insulin resistance and type 2 diabetes. However, its functional role is needed to be clarified. The role of IGFBP2 in type 2 diabetes may be related with regulation of IGFs, glucose uptake, and PI3K/Akt pathway, which indicates that IGFBP2 may have a specific role in the pathway of insulin resistance, either by dependent- or independent-IGF signaling pathway.

\subsection{IGFBP2 Is Associated with Metabolic Syndrome}

Metabolic syndrome is a cluster of well-defined conditions, that include increased blood pressure, high blood glucose, obesity, characterized by increased abdominal fat, and increased circulating lipid levels, such as cholesterol and triglycerides. Metabolic syndrome patients have typically increased risk of type 2 diabetes.

IGFBP2, as a potential risk factor of insulin sensitivity, is related with metabolic syndrome. Heald et al. (2006) reported in 163 type 2 diabetes patients that 125 of those patients with metabolic syndrome patients presented lower levels of IGFBP2 than those in 38 nonmetabolic syndrome participants [4]. This study also showed that low serum IGFBP2 was associated with elevated fasting glucose, triglycerides, and low-density lipoprotein (LDL)cholesterol and positively correlated with insulin sensitivity, which could be a possible biomarker for metabolic syndrome. The notion that supports the implication of IGFBP2 with metabolic syndrome is that low IGFBP2 levels are associated with a deleterious lipid profile. Accordingly, Carter and colleagues (2014) reported that low serum IGFBP2 levels were associated with impaired insulin sensitivity, increased fat mass and higher plasma 
triglycerides, by studying 379 Caucasian men. In addition, serum IGFBP2 levels were significantly and independently associated with very LDL-triglycerides levels, which concludes in a metabolic alterations, being an early dyslipidemia but also for main cluster for metabolic syndrome [71]. But IGFBP2 is also associated with a deleterious blood pressure profile. Olszanecka and collaborators (2017) reported that 152 hypertensive women had significantly lower serum IGFBP2 levels than 40 non-hypertensive women and was negatively correlated with 24-h systolic blood pressure. Indeed, this study showed a negative correlation with a number of metabolic syndrome components [72]. Moreover, a recent study, conducted by Pouriamehr et al. (2019) confirmed that 110 metabolic syndrome patients have a lower level of IGFBP2 compared with subjects in the control group [73].

As already mentioned, the role of IGFBP2 on metabolic syndrome needs to be studied in depth. The association of IGFBP2 with metabolic syndrome variables may explain in part its potential role in developing metabolic disease. The role of IGFBP2 in glucose intake, insulin sensitivity, including insulin resistance, lipid profile, and obesity may contribute to metabolic syndrome. Anyway, higher concentration of IGFBP2 at baseline was associated with a lower risk of incident metabolic syndrome [74], and vice versa.

\subsection{Proposed Mechanisms of IGFBP2 in Obesity-Related Insulin Resistance}

Our proposed mechanism by which IGFBP2 exerts preventive properties in obesity, begins with the ability that IGFBP2 has to prevent and inhibit adipogenesis at local visceral adipose tissue. Adequate serum levels of IGFBP2 inhibit differentiation of preadipocytes, and further hyperplasia and hypertrophy of visceral adipose tissue in both dependent and independent actions, which results in preventing obesity state (Figure 3). The action of IGFBP2 could occur at IGF-dependent manner, in which IGFBP2 modulates the action of IGFs in preadipocytes, by inhibiting adipogenesis. It has been demonstrated that IGF1 stimulates proliferation of 3T3-L1 preadipocytes through activation of MAPK, which is mediated through the Src family of nonreceptor tyrosine kinases [75]. Likewise, the action of IGFBP2 through IGF-independent pathway is related to its interaction with integrin. A study reported that knockdown of integrin reduced the proliferation of human adipose tissue stem cells, and promoted adipogenic differentiation. This action is carried out by the RGD domain and its interaction with integrins, suggesting a negative impact of RDG-motif signaling on adipogenic differentiation of human adipose tissue stem cells via integrin [76,77]. Integrin activates rapidly accelerated fibrosarcoma (RAF) and then extracellular signal-regulated kinase (ERK). ERK inhibits GSK3 $\beta$, which in turn inhibits $\beta$-catenin and adipogenesis [76]. The HBD2 domain also may reduce gain in total fat mass and visceral fat accumulation and inhibits adipogenesis [49].

In obese state, a combination of risk factors leads to reduce serum IGFBP2 levels. Unhealthy way of life, including overeating, hypercaloric diet, high protein diet, and low consumption of carbohydrates and unsaturated fat, as well as low physical activity, has been linked to decreased IGFBP2 circulating levels. Low IGFBP2 levels do not regulate adequately the local action of IGFs at adipose tissue levels, resulting in increasing rate of adipogenesis by IGFs. In addition, a low activity of integrin at preadipocytes decreases the activity of RAF and ERK, inhibits GSK $3 \beta$, and activates $\beta$-catenin, then results in the progression of the adipogenesis process. HBD2 does not exert its correct function by inhibiting adipogenesis at correct rate as well.

As regarding to insulin sensitivity and insulin resistance, the proposed mechanism by which IGFBP2 improves insulin sensitivity, is through IGFs/IGFBP2-dependent and independent model. IGFs has the ability to activate the translocation of GLUT4 through the activation of Akt, and when IGFBP2 binds to integrins, this interaction results in the phosphorylation of PTEN and inactivation of their functions. PTEN acts as a negative regulator of insulin signaling in skeletal muscle and adipocytes. The inhibition of PTEN increases the activity of PI3K, which results in the translocation of GLUT4 from cytoplasm to surface cell. Thus, IGFBP2 participates in the regulation of glucose metabolism and insulin sensitivity through PI3K/Akt activity by an independent-manner of IGFs (Figure 3). The improve- 
ment of insulin sensitivity through IGFBP2 is dose-IGFBP2 dependent, in which adequate levels of IGFBP2 mark the action of both insulin and IGFs on glucose uptake into the cells. In addition, the activation of IGF2R by the modulation of IGF2/IGFBP2 leads to the translocation of GLUT4 and improves glucose uptake [33,34].

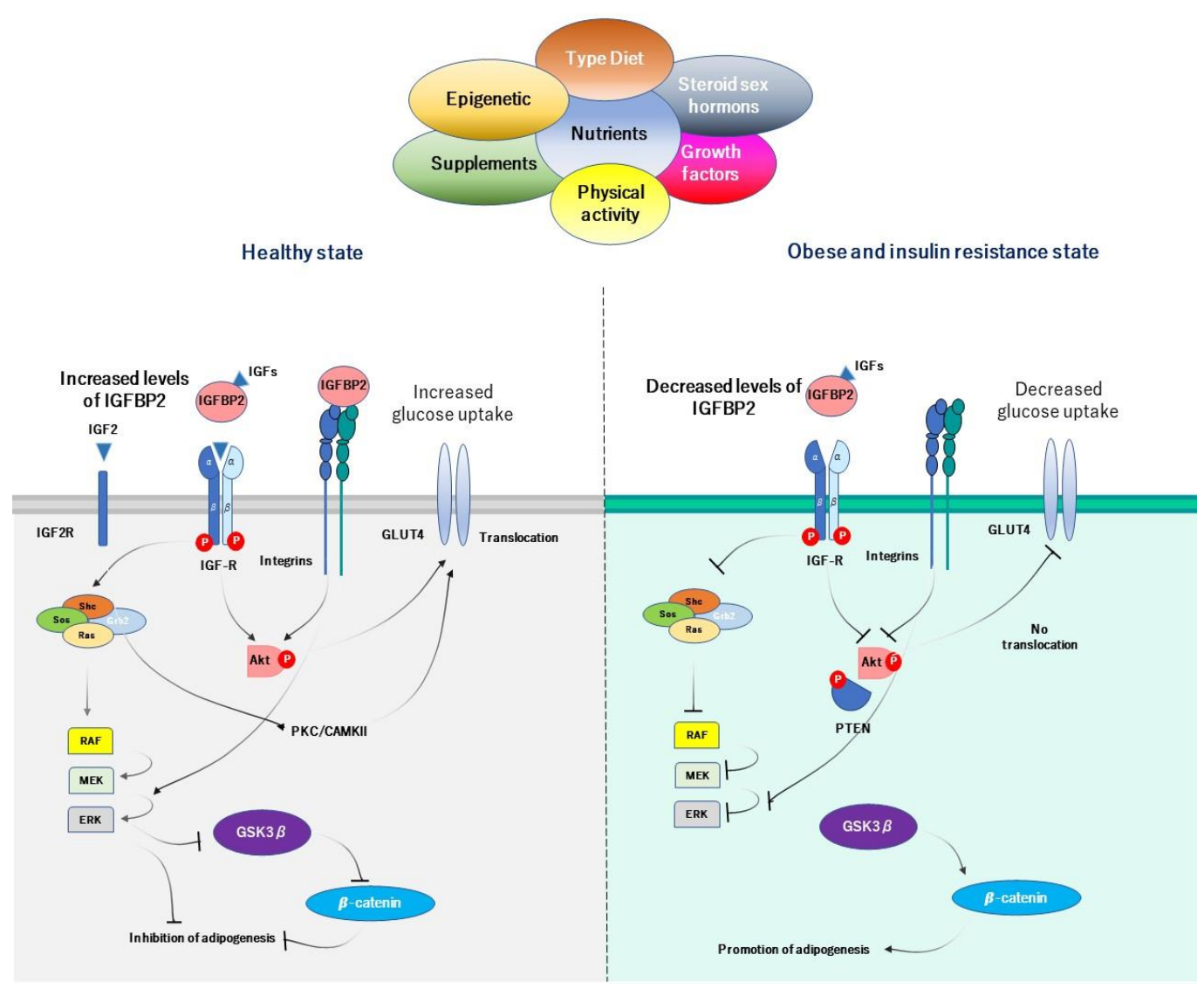

Figure 3. Proposed mechanism of action of IGFBP2 in obesity and insulin sensitivity. Dietary components and lifestyle modifications could affect circulating levels and mRNA expression of IGFBP2. The combination of these factors could provide a functional role of IGFBP2 on several metabolic disorders, and assign different strategies of prevention. In health state, higher levels of IGFBP2 act in both dependent and independent models to inhibit adipogenesis and activate the translocation of GLUT4, and improve the insulin sensitivity. In obese and insulin resistant state, lower IGFBP2 levels are the results of multiple factors, such as diet, sedentary, and low component and supplement from diet. When IGFBP2 is decreased, the adipogenesis process is activated and the translocation of GLUT4 is reduced, which results in increased body fat and poor insulin sensitivity.

\section{Diverse Strategies to Modify Serum IGFBP2 in a Prevention Context}

It has been demonstrated that many human tissues express IGFBP2 gene. IGFBP2 expression can be detected in brain, blood, mature adipocytes, and tumoral cells. In particular, IGFBP2 is highly expressed in the pancreas and liver, but liver and adipocytes are the most interesting tissues because of their role in the metabolism. Thus, the expression pattern of IGFBP2 is regulated under a cell-specific pathway, which its expression control is subject to a fine regulation between diet, lifestyle, and epigenetic interactions. All together, they regulate the expression of IGFBP2.

\subsection{Diet and Lifestyle Modifications}

The main function of IGFBP2, therefore, might be related with metabolic effect such as insulin, glucose, and lipid metabolism. Table 1 resumes the main nutrients that mod- 
ulate the concentration of IGFBP2 in serum. Pucilowska and colleagues showed in 1993, that IGFBP2 value before refeeding was twice in 22 children, and decreased after a high protein diet [78], although these children were infected with shigellosis. In 1995, Fouque et al. evaluated a 3-month controlled study in 12 adult chronic renal failure patients with low protein diet. After a 4- to 6-week equilibrium period, serum IGFBP2 was significantly higher in chronic renal failure patients than normal adults [79]. In addition, in 2007, Vrieling and collaborators conducted a clinical trial in 40 men and 31 postmenopausal women with lycopene and green tea supplementation and found these supplements significantly increased serum IGFBP2 concentrations in both men and women than after placebo [80]. In 2009, Crowe et al. reported in a cross-sectional study of 4731 men and women, that the intake of carbohydrate, in particular, the intake of starch by not free sugar, and monounsaturated fat content were associated with increased IGFBP2 in plasma, whereas total and dairy animal protein were related to decreased IGFBP2 [81], which was further validated in 2012 in another cross-sectional study conducted by Young et al. [82]. Additionally, a study conducted in 2016 reported that the fruits and vegetables consumption in 265 mid-childhood and 261 adolescence was related to higher IGFBP2 in adulthood [83]. Nonetheless, other nutrients also modulate the bioavailability of IGFBP2. A cross-sectional proteomic study $(\mathrm{n}=16)$ conducted in 2018 showed that circulating vitamin D levels, upper to $50 \mathrm{nmol} / \mathrm{L}$, are correlated with increased plasma levels of IGFBP2 in men with obesity [84].

Table 1. Dietary and lifestyle components that alter the circulating levels of IGFBP2.

\begin{tabular}{|c|c|c|c|c|}
\hline Groups & Effectors & Effects of IGFBP2 & Physiological Context & Refs \\
\hline \multirow[t]{7}{*}{ Nutrients } & Vitamin D & $\uparrow$ & $\begin{array}{c}\text { Men with obesity with high vitamin } \\
\text { D had increased IGFBP2 levels than } \\
\text { lower vitamin D subjects }\end{array}$ & [84] \\
\hline & Protein & $\downarrow$ & $\begin{array}{l}\text { High protein diet was associated } \\
\text { with decreased serum IGFBP2 levels }\end{array}$ & [81] \\
\hline & Calcium & $\downarrow$ & $\begin{array}{c}\text { High calcium diet was associated } \\
\text { with decreased serum IGFBP2 levels } \\
\text { High carbohydrates diet was }\end{array}$ & [81] \\
\hline & Carbohydrates & $\uparrow$ & $\begin{array}{l}\text { associated with increased serum } \\
\text { IGFBP2 levels }\end{array}$ & [81] \\
\hline & Monounsaturated fat & $\uparrow$ & $\begin{array}{l}\text { High monounsaturated diet was } \\
\text { associated with increased serum } \\
\text { IGFBP2 circulating levels }\end{array}$ & [81] \\
\hline & $\begin{array}{l}\text { Lycopene and } \\
\text { green tea }\end{array}$ & $\uparrow$ & $\begin{array}{l}\text { A randomized, placebo-controlled, } \\
\text { double-blinded crossover study } \\
\text { showed that lycopene and green tea } \\
\text { supplements were associated with } \\
\text { increased serum IGFBP2 }\end{array}$ & [80] \\
\hline & $\begin{array}{l}\text { Fruits and } \\
\text { flavonoid intake }\end{array}$ & $\uparrow$ & $\begin{array}{l}\text { High fruits and flavonoid intake was } \\
\text { associated with increased serum } \\
\text { IGFBP2 circulating }\end{array}$ & [83] \\
\hline \multirow[t]{3}{*}{ Growth factors } & Insulin & $\uparrow$ & $\begin{array}{l}\text { Insulin increased IGFBP2 in cultured } \\
\text { embryonic kidney cell line }\end{array}$ & [85] \\
\hline & $\begin{array}{l}\text { IGF1, IGF2 and } \\
\text { IGF analogues }\end{array}$ & $\uparrow$ & $\begin{array}{l}\text { IGF1, IGF2 and IGF analogues } \\
\text { increase IGFBP2 levels in human } \\
\text { subjects and different cell models } \\
\text { Leptin stimulates expression of }\end{array}$ & [6,85-90] \\
\hline & Leptin & $\uparrow$ & $\begin{array}{l}\text { IGFBP } 2 \text { and increases protein levels } \\
\text { in human skeletal muscle cells }\end{array}$ & [52] \\
\hline Physical activity & $\begin{array}{l}\text { Endurance and } \\
\text { resistance exercises }\end{array}$ & $\uparrow$ & $\begin{array}{l}\text { Physical activity was associated } \\
\text { with increased serum IGFBP2 }\end{array}$ & [91], [92] \\
\hline
\end{tabular}

These aforementioned findings suggest that IGFBP2 seems to be particularly sensitive to diet. Therefore, a personalized diet strategy could be considered beneficial for health, related to IGFBP2 levels. Accordingly, there is growing evidence that personalized diet could 
modify serum IGFBP2. In 2002, a cross-sectional study of 292 British women conducted in a plant-based (vegan) diet showed that the mean concentrations of serum IGFBP2 were $20-40 \%$ higher in vegan women compared to meat-eaters and vegetarians [93]. In 2005, 34 obese subjects were subjected to 8 weeks with very low-calorie diet (VLCD), followed by 12 weeks with a weight-stabilizing diet. After 20 weeks, serum IGFBP2 was increased in comparison with baseline [94]. A few years later, in 2012, Touskova et al. confirmed these results, showing that after VLCD, 13 obese women with type 2 diabetes showed increased IGFBP2 expression in subcutaneous adipose tissue [95]. Recently, in 2019, Carter and colleagues conducted a longitudinal one-year lifestyle modification program consisting in personalized healthy eating and physical activity counseling, combined to elicit a daily $500 \mathrm{kcal}$ deficit. The intervention triggered a 43\% increase of IGFBP2 levels in 99 participants, and subjects with the most substantial increases in IGFBP2 also experienced the most important metabolic improvements [96].

In summary, results from the previous studies of dietary factors and the concentrations of IGFBP2 show a number of potentially important associations. The key findings were that higher intakes of protein and low carbohydrate and monounsaturated fats were related to decreased concentrations of serum IGFBP2. These associations may be important to understand the etiology of IGFBP2 in metabolic disorders associated with diet.

\subsection{The Effect of Physical Activity on Serum IGFBP2}

Physical activity is a key modifier of IGFBP2, since it is considered a potential modulator of circulating IGFBP2. The endurance exercise training shows to have an effect on the mRNA expression of IGFBP2 in skeletal muscle. Kopple et al. demonstrated in 2006, that IGFBP2 expression was increased at the end of exercise training in 10 sedentary maintenance hemodialysis patients who underwent exercise [97]. In 2008, Berg et al. evaluated the effect of ultra-endurance exercise on serum IGFBP2. Results showed an increasing serum IGFBP2 levels in only 7 endurance athlete women after 24 hours [91], suggesting a possible relationship with female hormone such as estradiol, since previous studies reported that estrogen is a negative regulator of IGFBP2 in plasma [98].

Otherwise, endurance training also was able to increase IGFBP2, by Gregory and colleagues (2013) [92]. Indeed, an interaction between diet and exercise are noted in a previous study conducted by Foster et al. (2012) [99]. Eight college-aged males completed three high-intensity interval training protocols followed by three post-exercise nutritional protocols with placebo, carbohydrate only, and essential amino acid/carbohydrate. Significant differences were noted in IGFBP2 only in the placebo group, in which IGFBP2 was significantly increased. Likewise, Nindl et al. (2016) evaluated differential responses of the IGF system in resistance exercise-based program, during an acute resistance exercise protocol in 33 volunteers. This study found that after 4 and 8 weeks of training, serum IGFBP2 was significantly increased in comparison with baseline value [100]. Accordingly, a recent study confirmed the previous results. Four weeks of high-intensity exercise training resulted in a statistically significant change in the plasma level of IGFBP2 and further eight months of intensive exercise also resulted in a significant increase of IGFBP2 [101].

As already noted, diverse exercise strategies are commented to modulate the levels of serum IGFBP2. These strategies may be taken account in the management of many chronic noncommunicable diseases, such as type 2 diabetes and obesity. A strategic plan and modification of lifestyle, which contain balanced diet (high carbohydrates and monounsaturated fat, moderate-protein intake) and physical activity (both endurance and resistance exercise) could be essential in the design study of evaluating serum IGFBP2, and also as preventive strategies in non-communicable diseases.

\subsection{Epigenetic Regulation also Influences IGFBP2}

The epigenetic landscape of IGFBP2 is still premature and need to be assessed with caution. However, there is evidence supporting the idea that epigenetic changes at the promoter of IGFBP2 cause strong modification in the IGFBP2 expression and further IGFBP2 
bioavailability. In 2005, Chiba et al. showed aberrant methylation of IGFBP2 in hepatoma cancer, linking IGFBP2 as a tumor suppressor gene [102]. In this line, Sato and colleagues (2006) illustrated that IGFBP2 promoter has CpG islands located at the proximal regulatory elements, which is frequently methylated [8]. There is a CpG-rich region, which it is proposed as a genetic regulator. The transcription factor TFIID binds to CG-rich sequences in the IGFBP2 promoter, and initiates RNA transcription. A hypermethylated status of this regions may influence the ability of these transcription factors to bind in, and further regulate the initiation of RNA transcription. Indeed, Zheng et al. (2011) found IGBP2 hypermethylation profiles specific for glioma subtypes and it was associated with low IGFBP 2 mRNA expression [103]. Additionally, another study conducted by Ahrens et al. (2013) evaluated the DNA methylation analysis in 45 nonalcoholic fatty liver (NASH) patients, and found that IGFBP2 locus was hypermethylated in NASH, suggesting a potential role in metabolic disorders at the epigenetic levels [104]. Moreover, a study conducted by Nawathe et al. (2016) investigated the relationship between DNA methylation of components of the IGF axis in the placenta and disorders in fetal growth. This study found that the CpG methylation of the IGFBP2 promoter was lower in the placenta from small gestational age neonates as compared to appropriately grown neonates, but was unchanged in the placenta from large gestational age neonates [105]. Interestingly, a recent study reported that silenced IGFBP2 acts as a tumor suppressor gene in epithelial bladder cancer cells. Silencing IGFBP2 by siRNA promotes cell proliferation and invasion. This study showed that IGFBP2 was epigenetically silenced via DNA methylation. The exposition of cancer cells to methylation inhibitor (5-Aza-2'-Deoxycytidine (AZA)), produced re-expression of IGFBP2, and increased in abundance of IGFBP2, indicating that IGFBP2 could be epigenetically silenced [106]. In the same years, Zhang et al. showed that IGFBP2 DNA methylation levels in visceral adipose tissue were increased in obese subjects, and increased when compared to the IGFBP2 DNA methylation in subcutaneous adipose tissue, irrespective of obesity [50], suggesting a specific-depot epigenetic alteration in the IGFBP2 regulation.

At histone modification levels, different molecules use diverse strategies to increase IGFBP2 levels. Biernacka et al. (2013) reported that glucose increased IGFBP2 via increasing the acetylation status of histones $\mathrm{H} 3$ and $\mathrm{H} 4$ associated with the IGFBP2 gene promoter [107]. In 2015, Pickard et al. demonstrated that using 3-dimensional organotypic cultures, that repression of IGFBP2 is mediated by histone deacetylation at the IGFBP2 promoter and was reversed by treatment with histone deacetylase (HDAC) inhibitors [108]. Likewise, Phillip and collaborators (2016) further reported that deficient-IGFBP2 glioma cell treatment with IGFBP2 resulted in a rapid increase of lysine-specific demethylase 1 (LSD1) and methylated histones that have been identified as direct targets of LSD1 (H3K9 and H3K27). The process has been shown to be reversible, suggesting a possible role of IGFBP2 at epigenetic regulation and specifically affected epigenetic factors. [109]. Indeed, the inhibition of LSD1 increases the methylation levels of H3K4 at the promoter site of IGFBP2, indicating that IGFBP2 is regulated under histone modification levels [110]. However, the inactivation of histone deacetylase sirtuin 6 (SIRT6) acts as histone deacetylation at IGFBP2 promoter and inhibits IGFBP2 expression. Haploinsufficiency of SIRT6, but not complete loss of SIRT6 promotes IGFBP2 expression via increased chromatin accessibility, by H3K56 acetylation at the IGFBP2 locus. Overall, modification at histone levels in the promotor of IGFBP2 increases cell development and cell survival [111].

Therefore, the promoter of IGFBP2 is highly regulated by epigenetic modifications, indicating that IGFBP2 is sensible to epigenetic reprogramming. It is worth mentioning that epigenetic mechanism on IGFBP2 was not linked with a determined phenotype. However, nutrients were widely associated with epigenetic reprogramming. Therefore, the interaction of epigenetic landscape of IGFBP2 with nutritional compounds, diet, and lifestyle modifications may be a topic of interest. 


\section{Preclinical Pharmacology Studies of IGFBP2}

IGFBP2 has potent beneficial therapeutic action in obesity and insulin resistance. To explore the effect of IGFBP2 on the development of diet-induced obesity and its metabolic consequences, Weathcroft et al. (2007) evaluated the effect of high-fat/high calorie diet for 32 weeks in IGFBP2 transgenic mice. Weight gain on the high-fat diet was attenuated in transgenic mice compared with wild-type mice. Wild-type mice markedly increased their fat depots, whereas IGFBP2 transgenic mice remained lean. In addition, blood glucose after a glucose tolerance test was significantly lower in IGFBP2 than wild-type mice on both types of diet, suggesting that IGFBP2 protects against obesity and insulin resistance [48]. Likewise, Hedbacker et al. (2010) evaluated the effect of IGFBP2 in obesity and insulin sensitivity. IGFBP2 was injected into streptozotocin-induced insulin-deficient mice. At day 5 after IGFBP2 injections, control mice had increased fasting glucose compared to the IGFBP2-treated group. The glucose tolerance test was also markedly improved at $45 \mathrm{~min}$. Otherwise, the ob/ob expressed-IGFBP2 mice showed decreased weight and food intake, decrease fasting glucose and insulin and glucose tolerance [51].

Despite its multiple metabolic benefits, human IGFBP2 in its native form may be not enough suitable for clinical use owing to its pharmacokinetic profiles. In addition, native IGFBP2 is susceptible to proteolytic cleavage in the middle region and further inactivation. As suggested, HBD2 peptide is more effective in in vivo and IGFBP2 ${ }^{-/-}$ mice. The administration of HBD2 to IGFBP2 ${ }^{-1-}$ mice reduced gain in total fat mass and visceral fat accumulation. The HBD2 peptide also increased serum leptin, suggesting that HBD2 domain of IGFBP2 is the primary region that accounts for its ability to inhibit adipogenesis [49]. Therefore, various biopharmaceutical engineering approaches may be adopted to develop IGFBP2 analogues and mimetics with improved physiological properties in obesity and insulin sensitivity, pharmacokinetic profiles and potency that are suitable for future clinical development.

\section{Concluding Remarks and Future Perspectives}

The major conclusions that can be drawn from this review are that IGFBP2 is sensitive to relevant changes in our lifestyle. There are evidences that serum levels vary with large number of diet component and physical activity. Thus, restoring IGFBP2 levels by a lifestyle modification program or by new therapeutic strategies could be interesting, in which increased levels of IGFBP2 are associated with improvements of metabolic variables in obesity and insulin sensitivity. Indeed, IGFBP2 could be also interesting to use as an early marker and monitoring for several metabolic diseases, such as obesity, metabolic syndrome, type 2 diabetes, or insulin resistance. In this line, serum IGFBP2 concentrations could allow for scientists and physicians to monitor the improvement of lifestyle modification and treatment intervention. However, further studies are needed to determine a consensus modification lifestyle program. The current perspective is that IGFBP2 is decreased in metabolic disorders, in which several risk factors lead to decreased IGFBP2 levels, under different molecular targets, including epigenetic, transcriptional, and protein levels. Future works are needed to establish new strategies to use IGFBP2 in anti-obesity and related diseases treatment. In addition, we also need to understand many of IGFBP2 pathways that are implicated, since more knowledges about this issue could help us to find new strategies pathway in metabolic diseases. Our opinions about the role of IGFBP2 in obesity-related insulin resistance research, is that we may consider a cohort that has controlling lifestyle habits, diet and supplements, and new therapeutic options. It is also important to consider biochemical parameters and value the effect of antidiabetic on IGFBP2 concentrations to understand better the role of IGFBP2 in non-communicable diseases. 
Author Contributions: Conceptualization, M.M.-G., J.L.-M. and F.J.T.; writing-original draft preparation, H.B. and E.M.Y.-S.; writing-review and editing, H.B., M.M.-G., F.J.T. and E.M.Y.-S.; funding acquisition, M.M.-G. and F.J.T. All authors have read and agreed to the published version of the manuscript.

Funding: This study was supported by "Centros de Investigación En Red" (CIBER) of the "Instituto de Salud Carlos III" (ISCIII) and by grants from ISCIII (PI18/01399 and PI18/01160) and cofinanced by the European Regional Development Fund (FEDER). HB is supported by a predoctoral fellowship ("Plan Propio IBIMA 2020 A.1 Contratos predoctorales", Ref.: predoc20_002) M.M.G. was the recipient of the Nicolas Monardes Programme from the "Servicio Andaluz de Salud, Junta de Andalucia", Spain (RC-0001-2018 and C-0029-2023). E.Y. was the recipient of the Nicolas Monardes Programme from the "ServicioAndaluz de Salud, Junta de Andalucia", Spain (C1-0005-2019).

Institutional Review Board Statement: Not applicable.

Informed Consent Statement: Not applicable.

Data Availability Statement: Data sharing not applicable.

Conflicts of Interest: The authors declare no conflict of interest.

\begin{tabular}{|c|c|}
\hline p53 & transformation-related protein 53 \\
\hline NFIA & nuclear factor IA \\
\hline PPRE & peroxisome-proliferator activated receptor responsive element \\
\hline E-Box & enhancer box \\
\hline bHLH & Basic helix-loop-helix \\
\hline EGFR1 & epidermal growth factor receptor 1 \\
\hline Sp1 & specificity protein 1 \\
\hline IGF1 & insulin growth factor type 1 \\
\hline HBD1 & heparin binding domain 1 \\
\hline NLS & nuclear localization sequence; \\
\hline HBD2 & heparin binding domain \\
\hline RGD & tripeptide Arg-Gly-Asp \\
\hline PDB & Protein data bank \\
\hline IGFBP2 & insulin growth factor binding protein 2 . \\
\hline IGF2 & Insulin growth factor 2; \\
\hline IGF2R & Insulin growth factor receptor type 2 \\
\hline IGF1R & Insulin growth factor receptor type 1 \\
\hline Shc & SHC Adaptor Protein \\
\hline SOS & Son of Sevenless \\
\hline Ras & rat sarcoma \\
\hline Grb2 & growth factor receptor-bound protein 2 \\
\hline IRS1 & Insulin receptor substrate 1 \\
\hline PI3K & phosphatidylinositol 3-kinase \\
\hline PIP2 & Phosphatidylinositol 4,5-bisphosphate \\
\hline PIP3 & Phosphatidylinositol 3,4,5-trisphosphate \\
\hline GLU4 & glucose receptor type 4 \\
\hline MAPK & mitogen activated protein kinase \\
\hline RAF & Rapidly Accelerated Fibrosarcoma \\
\hline MEK & Mitogen-activated protein kinase kinase \\
\hline ERK & extracellular signal-regulated kinase \\
\hline PKC/CAMKII & protein kinase $\mathrm{C}$ /calcium/calmodulin dependent protein kinase I \\
\hline PDK & Pyruvate dehydrogenase kinase \\
\hline Akt & alpha serine/threonine-protein kinase \\
\hline RPTP $\beta$ & tyrosine phosphatase $\beta$ \\
\hline PAPA1 & Pim-1-associated protein-1 \\
\hline P21 & cyclin-dependent kinase inhibitor 1 \\
\hline VEGF & vascular endothelial growth factor \\
\hline GSK3 $\beta$ & glycogen synthase kinase $3 \beta$ \\
\hline
\end{tabular}




\section{References}

1. Rosenfeld, R.G. Insulin-like Growth Factors and the Basis of Growth. N. Engl. J. Med. 2003, 349, 2184-2186. [CrossRef] [PubMed]

2. Riedemann, J.; Macaulay, V.M. IGF1R signalling and its inhibition. Endocr. Relat. Cancer 2006, 13, S33-S43. [CrossRef] [PubMed]

3. Allard, J.B.; Duan, C. IGF-Binding Proteins: Why Do They Exist and Why Are There So Many? Front. Endocrinol. 2018, 9, 117. [CrossRef] [PubMed]

4. Heald, A.H.; Kaushal, K.; Siddals, K.W.; Rudenski, A.S.; Anderson, S.G.; Gibson, J.M. Insulin-like Growth Factor Binding Protein-2 (IGFBP-2) is a Marker for the Metabolic Syndrome. Exp. Clin. Endocrinol. Diabetes 2006, 114, 371-376. [CrossRef] [PubMed]

5. Binkert, C.; Margot, J.B.; Landwehr, J.; Heinrich, G.; Schwander, J. Structure of the human insulin-like growth factor binding protein-2 gene. Mol. Endocrinol. 1992, 6, 826-836. [CrossRef]

6. Zapf, J.; Schmid, C.; Guler, H.P.; Waldvogel, M.; Hauri, C.; Futo, E.; Hossenlopp, P.; Binoux, M.; Froesch, E.R. Regulation of binding proteins for insulin-like growth factors (IGF) in humans. Increased expression of IGF binding protein 2 during IGF I treatment of healthy adults and in patients with extrapancreatic tumor hypoglycemia. J. Clin. Investig. 1990, 86, 952-961. [CrossRef] [PubMed]

7. Cunningham, F.; Achuthan, P.; Akanni, W.; Allen, J.; Amode, M.R.; Armean, I.M.; Bennett, R.; Bhai, J.; Billis, K.; Boddu, S.; et al. Ensembl 2019. Nucleic Acids Res. 2019, 47, D745-D751. [CrossRef]

8. Sato, H.; Yazawa, T.; Suzuki, T.; Shimoyamada, H.; Okudela, K.; Ikeda, M.; Hamada, K.; Yamada-Okabe, H.; Yao, M.; Kubota, Y.; et al. Growth Regulation via Insulin-Like Growth Factor Binding Protein-4 and -2 in Association with Mutant K-ras in Lung Epithelia. Am. J. Pathol. 2006, 169, 1550-1566. [CrossRef]

9. Galea, C.A.; Mobli, M.; McNeil, K.A.; Mulhern, T.D.; Wallace, J.C.; King, G.F.; Forbes, B.E.; Norton, R.S. Insulin-like growth factor binding protein-2: NMR analysis and structural characterization of the N-terminal domain. Biochimie 2012, 94, 608-616. [CrossRef]

10. Grimberg, A.; Coleman, C.M.; Shi, Z.; Burns, T.F.; MacLachlan, T.K.; Wang, W.; El-Deiry, W.S. Insulin-like growth factor binding protein-2 is a novel mediator of p53 inhibition of insulin-like growth factor signaling. Cancer Biol. Ther. 2006, 5, 1408-1414. [CrossRef]

11. Yazawa, T.; Sato, H.; Shimoyamada, H.; Okudela, K.; Woo, T.; Tajiri, M.; Ogura, T.; Ogawa, N.; Suzuki, T.; Mitsui, H.; et al. Neuroendocrine Cancer-Specific Up-Regulating Mechanism of Insulin-Like Growth Factor Binding Protein-2 in Small Cell Lung Cancer. Am. J. Pathol. 2009, 175, 976-987. [CrossRef] [PubMed]

12. Mireuta, M.; Darnel, A.; Pollak, M. IGFBP-2 expression in MCF-7 cells is regulated by the PI3K/AKT/mTOR pathway through Sp1-induced increase in transcription. Growth Factors 2010, 28, 243-255. [CrossRef] [PubMed]

13. Lee, C.-C.; Chen, P.-H.; Ho, K.-H.; Shih, C.-M.; Cheng, C.-H.; Lin, C.-W.; Cheng, K.-T.; Liu, A.-J.; Chen, K.-C. The microRNA-302binhibited insulin-like growth factor-binding protein 2 signaling pathway induces glioma cell apoptosis by targeting nuclear factor IA. PLOS ONE 2017, 12, e0173890. [CrossRef] [PubMed]

14. Boughanem, H.; Cabrera-Mulero, A.; Millán-Gómez, M.; Garrido-Sánchez, L.; Cardona, F.; Tinahones, F.J.; Moreno-Santos, I.; Macías-González, M.; Mulero, C.-; Millán-Gómez, M.; et al. Transcriptional Analysis of FOXO1, C/EBP- and PPAR-2 Genes and Their association with Obesity-Related Insulin Resistance. Genes 2019, 10, 706. [CrossRef]

15. Badinga, L.; Song, S.; Simmen, R.C.M.; A Simmen, F. A Distal Regulatory Region of the Insulin-Like Growth Factor Binding Protein-2 (IGFBP-2) Gene Interacts with the Basic Helix-Loop-Helix Transcription Factor, AP-4. Endocrine 1998, 8, 281-290. [CrossRef]

16. Firth, S.M.; Baxter, R.C. Cellular Actions of the Insulin-Like Growth Factor Binding Proteins. Endocr. Rev. 2002, $23,824-854$. [CrossRef]

17. Graham, M.E.; Kilby, D.M.; Firth, S.M.; Robinson, P.J.; Baxter, R.C. Thein VivoPhosphorylation and Glycosylation of Human Insulin-like Growth Factor-binding Protein-5. Mol. Cell. Proteom. 2007, 6, 1392-1405. [CrossRef]

18. Shen, X.; Xi, G.; Maile, L.A.; Wai, C.; Rosen, C.J.; Clemmons, D.R. Insulin-Like Growth Factor (IGF) Binding Protein 2 Functions Coordinately with Receptor Protein Tyrosine Phosphatase and the IGF-I Receptor To Regulate IGF-I-Stimulated Signaling. Mol. Cell. Biol. 2012, 32, 4116-4130. [CrossRef]

19. Azar, W.J.; Zivkovic, S.; A Werther, G.; Russo, V.C. IGFBP-2 nuclear translocation is mediated by a functional NLS sequence and is essential for its pro-tumorigenic actions in cancer cells. Oncogene 2014, 33, 578-588. [CrossRef]

20. Sala, A.; Capaldi, S.; Campagnoli, M.; Faggion, B.; Labò, S.; Perduca, M.; Romano, A.; Carrizo, M.E.; Valli, M.; Visai, L.; et al. Structure and Properties of the C-terminal Domain of Insulin-like Growth Factor-binding Protein-1 Isolated from Human Amniotic Fluid. J. Biol. Chem. 2005, 280, 29812-29819. [CrossRef]

21. Mark, S.; Kübler, B.; Höning, S.; Oesterreicher, S.; John, H.; Braulke, T.; Forssmann, W.-G.; Ständker, L.; Kuebler, B. Diversity of Human Insulin-like Growth Factor (IGF) Binding Protein-2 Fragments in Plasma: Primary Structure, IGF-Binding Properties, and Disulfide Bonding Patternt. Biochemie 2005, 44, 3644-3652. [CrossRef] [PubMed]

22. Kuang, Z.; Yao, S.; Keizer, D.W.; Wang, C.C.; Leon, B.; Forbes, B.E.; Wallace, J.C.; Norton, R.S. Structure, Dynamics and Heparin Binding of the C-terminal Domain of Insulin-like Growth Factor-binding Protein-2 (IGFBP-2). J. Mol. Biol. 2006, 364, 690-704. [CrossRef] [PubMed]

23. Patil, S.S.; Gokulnath, P.; Bashir, M.; Shwetha, S.D.; Jaiswal, J.; Shastry, A.H.; Arimappamagan, A.; Santosh, V.; Kondaiah, P. Insulin-like growth factor binding protein- 2 regulates $\beta$-catenin signaling pathway in glioma cells and together contributes to poor patient prognosis. Neuro-Oncology 2016, 18, now053-1497. [CrossRef] [PubMed] 
24. Russo, V.C.; Schutt, B.S.; Andaloro, E.; Ymer, S.I.; Hoeflich, A.; Ranke, M.B.; Bach, L.A.; Werther, G.A. Insulin-Like Growth Factor Binding Protein-2 Binding to Extracellular Matrix Plays a Critical Role in Neuroblastoma Cell Proliferation, Migration, and Invasion. Endocrinology 2005, 146, 4445-4455. [CrossRef]

25. Wheatcroft, S.B.; Kearney, M.T. IGF-dependent and IGF-independent actions of IGF-binding protein-1 and -2: Implications for metabolic homeostasis. Trends Endocrinol. Metab. 2009, 20, 153-162. [CrossRef]

26. Rosenfeld, R.G.; Pham, H.; Conover, C.A.; Hintz, R.L.; Baxter, R.C. Structural and Immunological Comparison of Insulin-Like Growth Factor Binding Proteins of Cerebrospinal and Amniotic Fluids. J. Clin. Endocrinol. Metab. 1989, 68, 638-646. [CrossRef]

27. Alkharobi, H.; Alhodhodi, A.; Hawsawi, Y.; Alkafaji, H.; Devine, D.; El-Gendy, R.; Beattie, J. IGFBP-2 and -3 co-ordinately regulate IGF1 induced matrix mineralisation of differentiating human dental pulp cells. Stem Cell Res. 2016, 17, 517-522. [CrossRef]

28. Lund, J.; Søndergaard, M.T.; Conover, C.A.; Overgaard, M.T. Heparin-binding mechanism of the IGF2/IGF-binding protein 2 complex. J. Mol. Endocrinol. 2014, 52, 345-355. [CrossRef]

29. Kim, H.-S. Role of insulin-like growth factor binding protein-3 in glucose and lipid metabolism. Ann. Pediatr. Endocrinol. Metab. 2013, 18, 9-12. [CrossRef]

30. Pollak, M. The insulin and insulin-like growth factor receptor family in neoplasia: An update. Nat. Rev. Cancer 2012, 12, 159-169. [CrossRef]

31. Choi, Y.-S.; Cho, H.-Y.; Hoyt, K.R.; Naegele, J.R.; Obrietan, K. IGF-1 receptor-mediated ERK/MAPK signaling couples status epilepticus to progenitor cell proliferation in the subgranular layer of the dentate gyrus. Glia 2008, 56, 791-800. [CrossRef] [PubMed]

32. Ghosh, P.; Dahms, N.M.; Kornfeld, S. Mannose 6-phosphate receptors: New twists in the tale. Nat. Rev. Mol. Cell Biol. 2003, 4, 202-213. [CrossRef] [PubMed]

33. Chu, C.-H.; Tzang, B.-S.; Chen, L.-M.; Kuo, C.-H.; Cheng, Y.-C.; Chen, L.-Y.; Tsai, F.-J.; Tsai, C.-H.; Kuo, W.; Huang, C.-Y. IGF-II/mannose-6-phosphate receptor signaling induced cell hypertrophy and atrial natriuretic peptide/BNP expression via G $\alpha \mathrm{q}$ interaction and protein kinase C- $\alpha$ /CaMKII activation in H9c2 cardiomyoblast cells. J. Endocrinol. 2008, 197, 381-390. [CrossRef] [PubMed]

34. Kappel, V.D.; Zanatta, L.; Postal, B.G.; Silva, F.R.M.B. Rutin potentiates calcium uptake via voltage-dependent calcium channel associated with stimulation of glucose uptake in skeletal muscle. Arch. Biochem. Biophys. 2013, 532, 55-60. [CrossRef] [PubMed]

35. Ruoslahti, E. RGD and other recognition sequences for integrins. Annu. Rev. Cell Dev. Biol. 1996, 12, 697-715. [CrossRef]

36. Perks, C.M.; Vernon, E.G.; Rosendahl, A.H.; Tonge, D.; Holly, J.M.P. IGF-II and IGFBP-2 differentially regulate PTEN in human breast cancer cells. Oncogene 2007, 26, 5966-5972. [CrossRef]

37. Russo, V.C. Insulin-Like Growth Factor Binding Protein-2 Binds to Cell Surface Proteoglycans in the Rat Brain Olfactory Bulb. Endocrinology 1997, 138, 4858-4867. [CrossRef]

38. Xi, G.; Wai, C.; DeMambro, V.; Rosen, C.J.; Clemmons, D.R. IGFBP-2 Directly Stimulates Osteoblast Differentiation. J. Bone Miner. Res. 2014, 29, 2427-2438. [CrossRef]

39. Terrien, X.; Bonvin, E.; Corroyer, S.; Tabary, O.; Clément, A.; Henrion-Caude, A. Intracellular colocalization and interaction of IGF-binding protein-2 with the cyclin-dependent kinase inhibitor p21CIP1/WAF1 during growth inhibition. Biochem. J. 2005, 392, 457-465. [CrossRef]

40. Miyako, K.; Cobb, L.J.; Francis, M.; Huang, A.; Peng, B.; Pintar, J.E.; Ariga, H.; Cohen, P. PAPA-1 Is a Nuclear Binding Partner of IGFBP-2 and Modulates Its Growth-Promoting Actions. Mol. Endocrinol. 2009, 23, 169-175. [CrossRef]

41. Nam, S.Y.; Lee, E.J.; Kim, K.R.; Cha, B.S.; Song, Y.D.; Lim, S.K.; Lee, H.C.; Huh, K.B. Effect of obesity on total and free insulin-like growth factor (IGF)-1, and their relationship to IGF-binding protein (BP)-1, IGFBP-2, IGFBP-3, insulin, and growth hormone. Int. J. Obes. 1997, 21, 355-359. [CrossRef] [PubMed]

42. Ballerini, M.G.; Ropelato, M.G.; Domené, H.M.; A Pennisi, P.; Heinrich, J.J.; Jasper, H.G. Differential Impact of Simple Childhood Obesity on the Components of the Growth Hormone-Insulin-like Growth Factor (IGF)-IGF Binding Proteins Axis. J. Pediatr. Endocrinol. Metab. 2004, 17, 749-758. [CrossRef] [PubMed]

43. Yau, S.W.; E Harcourt, B.; Kao, K.-T.; Alexander, E.J.; Russo, V.C.; Werther, G.A.; Sabin, M.A. Serum IGFBP-2 levels are associated with reduced insulin sensitivity in obese children. Clin. Obes. 2018, 8, 184-190. [CrossRef] [PubMed]

44. Hu, D.; Pawlikowska, L.; Kanaya, A.; Hsueh, W.-C.; Colbert, L.; Newman, A.B.; Satterfield, S.; Rosen, C.; Cummings, S.R.; Harris, T.B.; et al. Serum Insulin-Like Growth Factor-1 Binding Proteins 1 and 2 and Mortality in Older Adults: The Health, Aging, and Body Composition Study. J. Am. Geriatr. Soc. 2009, 57, 1213-1218. [CrossRef] [PubMed]

45. Maffeis, C.; Benjamim, F.; Riccardo, B.; Massimiliano, C.; Francesco, B.; Luciano, C. Adipocytes IGFBP-2 Expression in Prepubertal Obese Children. Obesesity 2010, 18, 2055-2057. [CrossRef]

46. Ceccarini, G.; Pelosini, C.; Ferrari, F.; Magno, S.; Vitti, J.; Salvetti, G.; Moretto, C.; Marioni, A.; Buccianti, P.; Piaggi, P.; et al. Serum IGF-binding protein 2 (IGFBP-2) concentrations change early after gastric bypass bariatric surgery revealing a possible marker of leptin sensitivity in obese subjects. Endocrine 2019, 65, 86-93. [CrossRef]

47. Al-Regaiey, K.; Alshubrami, S.; Al-Beeshi, I.; Alnasser, T.; Alwabel, A.; Al-Beladi, H.; Al-Tujjar, O.; Alnasser, A.; Alfadda, A.A.; Iqbal, M. Effects of gastric sleeve surgery on the serum levels of GH, IGF-1 and IGF-binding protein 2 in healthy obese patients. BMC Gastroenterol. 2020, 20, 199. [CrossRef] 
48. Wheatcroft, S.B.; Kearney, M.T.; Shah, A.M.; Ezzat, V.A.; Miell, J.R.; Modo, M.; Williams, S.C.; Cawthorn, W.P.; Medina-Gomez, G.; Vidal-Puig, A.; et al. IGF-Binding Protein-2 Protects Against the Development of Obesity and Insulin Resistance. Diabetes 2007, 56, 285-294. [CrossRef]

49. Xi, G.; Solum, M.A.; Wai, C.; Maile, L.A.; Rosen, C.J.; Clemmons, D.R. The Heparin-Binding Domains of IGFBP-2 Mediate Its Inhibitory Effect on Preadipocyte Differentiation and Fat Development in Male Mice. Endocrinology 2013, 154, 4146-4157. [CrossRef]

50. Zhang, X.; Gu, H.F.; Frystyk, J.; Efendic, S.; Brismar, K.; Thorell, A. Analyses of IGFBP2 DNA methylation and mRNA expression in visceral and subcutaneous adipose tissues of obese subjects. Growth Horm. IGF Res. 2019, 45, 31-36. [CrossRef]

51. Hedbacker, K.; Birsoy, K.; Wysocki, R.W.; Asilmaz, E.; Ahima, R.S.; Farooqi, I.S.; Friedman, J.M. Antidiabetic Effects of IGFBP2, a Leptin-Regulated Gene. Cell Metab. 2010, 11, 11-22. [CrossRef] [PubMed]

52. Yau, S.W.; A Henry, B.; Russo, V.C.; McConell, G.K.; Clarke, I.J.; A Werther, G.; Sabin, M.A. Leptin Enhances Insulin Sensitivity by Direct and Sympathetic Nervous System Regulation of Muscle IGFBP-2 Expression: Evidence From Nonrodent Models. Endocrinology 2014, 155, 2133-2143. [CrossRef] [PubMed]

53. Neumann, U.H.; Chen, S.; Tam, Y.Y.C.; Baker, R.K.; Covey, S.D.; Cullis, P.R.; Kieffer, T.J. IGFBP2 Is Neither Sufficient nor Necessary for the Physiological Actions of Leptin on Glucose Homeostasis in Male ob/ob Mice. Endocrinology 2014, 155, 716-725. [CrossRef] [PubMed]

54. Clemmons, D.R.; Snyder, D.K.; Busby, W.H. Variables Controlling the Secretion of Insulin-Like Growth Factor Binding Protein-2 in Normal Human Subjects. J. Clin. Endocrinol. Metab. 1991, 73, 727-733. [CrossRef]

55. Arafat, A.M.; Weickert, M.O.; Frystyk, J.; Spranger, J.; Schöfl, C.; Mohlig, M.; Pfeiffer, A.F.H. The Role of Insulin-Like Growth Factor (IGF) Binding Protein-2 in the Insulin-Mediated Decrease in IGF-I Bioactivity. J. Clin. Endocrinol. Metab. 2009, 94, 5093-5101. [CrossRef]

56. Moreno-Santos, I.; Castellano-Castillo, D.; Lara, M.F.; Fernández-García, J.C.; Tinahones, F.J.; Macias-Gonzalez, M. IGFBP-3 Interacts with the Vitamin D Receptor in Insulin Signaling Associated with Obesity in Visceral Adipose Tissue. Int. J. Mol. Sci. 2017, 18, 2349. [CrossRef]

57. Beld, A.W.V.D.; Carlson, O.D.; E Doyle, M.; Rizopoulos, D.; Ferrucci, L.; Van Der Lely, A.J.; Egan, J.M. IGFBP-2 and aging: A 20-year longitudinal study on IGFBP-2, IGF-I, BMI, insulin sensitivity and mortality in an aging population. Eur. J. Endocrinol. 2019, 180, 109-116. [CrossRef]

58. Li, Z.; Miard, S.; Laplante, M.; Sonenberg, N.; Picard, F. Insulin stimulates IGFBP-2 expression in 3T3-L1 adipocytes through the PI3K/mTOR pathway. Mol. Cell. Endocrinol. 2012, 358, 63-68. [CrossRef]

59. Wilhelm, F.; Kässner, F.; Schmid, G.; Kratzsch, J.; Laner, A.; Wabitsch, M.; Körner, A.; Kiess, W.; Garten, A. Phosphatidylinositol 3-kinase (PI3K) signalling regulates insulin-like-growth factor binding protein-2 (IGFBP-2) production in human adipocytes. Growth Horm. IGF Res. 2015, 25, 115-120. [CrossRef]

60. Assefa, B.; Mahmoud, A.M.; Pfeiffer, A.F.H.; Birkenfeld, A.L.; Spranger, J.; Arafat, A.M. Insulin-Like Growth Factor (IGF) Binding Protein-2, Independently of IGF-1, Induces GLUT-4 Translocation and Glucose Uptake in 3T3-L1 Adipocytes. Oxidative Med. Cell. Longev. 2017, 2017, 1-13. [CrossRef]

61. Rajpathak, S.N.; He, M.; Sun, Q.; Kaplan, R.C.; Muzumdar, R.; Rohan, T.E.; Gunter, M.J.; Pollak, M.; Kim, M.; Pessin, J.E.; et al. Insulin-Like Growth Factor Axis and Risk of Type 2 Diabetes in Women. Diabetes 2012, 61, 2248-2254. [CrossRef] [PubMed]

62. Lappas, M.; Jinks, D.; Shub, A.; Willcox, J.; Georgiou, H.M.; Permezel, M. Postpartum IGF-I and IGFBP-2 levels are prospectively associated with the development of type 2 diabetes in women with previous gestational diabetes mellitus. Diabetes Metab. 2016, 42, 442-447. [CrossRef] [PubMed]

63. Zhu, Y.; Mendola, P.; Albert, P.S.; Bao, W.; Hinkle, S.N.; Tsai, M.Y.; Zhang, C. Insulin-Like Growth Factor Axis and Gestational Diabetes Mellitus: A Longitudinal Study in a Multiracial Cohort. Diabetes 2016, 65, 3495-3504. [CrossRef] [PubMed]

64. Wang, X.-R.; Wang, W.-J.; Yu, X.; Hua, X.; Ouyang, F.; Luo, Z.-C. Insulin-Like Growth Factor Axis Biomarkers and Gestational Diabetes Mellitus: A Systematic Review and Meta-Analysis. Front. Endocrinol. 2019, 10, 444. [CrossRef]

65. Wittenbecher, C.; Ouni, M.; Kuxhaus, O.; Jähnert, M.; Gottmann, P.; Teichmann, A.; Meidtner, K.; Kriebel, J.; Grallert, H.; Pischon, T.; et al. Insulin-Like Growth Factor Binding Protein 2 (IGFBP-2) and the Risk of Developing Type 2 Diabetes. Diabetes 2018, 68, 188-197. [CrossRef]

66. Noordam, R.; Van Heemst, D.; Suhre, K.; Krumsiek, J.; Mook-Kanamori, D.O. Proteome-wide assessment of diabetes mellitus in Qatari identifies IGFBP-2 as a risk factor already with early glycaemic disturbances. Arch. Biochem. Biophys. 2020, $689,108476$. [CrossRef]

67. Horikawa, Y.; Miyake, K.; Yasuda, K.; Enya, M.; Hirota, Y.; Yamagata, K.; Hinokio, Y.; Oka, Y.; Iwasaki, N.; Iwamoto, Y.; et al. Replication of Genome-Wide Association Studies of Type 2 Diabetes Susceptibility in Japan. J. Clin. Endocrinol. Metab. 2008, 93, 3136-3141. [CrossRef]

68. Cauchi, S.; Meyre, D.; Durand, E.; Proença, C.; Marre, M.; Hadjadj, S.; Choquet, H.; De Graeve, F.; Gaget, S.; Allegaert, F.; et al. Post Genome-Wide Association Studies of Novel Genes Associated with Type 2 Diabetes Show Gene-Gene Interaction and High Predictive Value. PLoS ONE 2008, 3, e2031. [CrossRef]

69. Huang, Q.; Yin, J.-Y.; Dai, X.-P.; Pei, Q.; Dong, M.; Zhou, Z.; Huang, X.; Yu, M.; Zhou, H.-H.; Liu, Z.-Q. IGF2BP2 variations influence repaglinide response and risk of type 2 diabetes in Chinese population. Acta Pharmacol. Sin. 2010, 31, 709-717. [CrossRef] 
70. Duesing, K.; Fatemifar, G.; Charpentier, G.; Marre, M.; Tichet, J.; Hercberg, S.; Balkau, B.; Froguel, P.; Gibson, F. Evaluation of the Association of IGF2BP2 Variants With Type 2 Diabetes in French Caucasians. Diabetes 2008, 57, 1992-1996. [CrossRef]

71. Carter, S.; Li, Z.; Lemieux, I.; Alméras, N.; Tremblay, A.; Bergeron, J.; Poirier, P.; Deshaies, Y.; Després, J.-P.; Picard, F. Circulating IGFBP-2 levels are incrementally linked to correlates of the metabolic syndrome and independently associated with VLDL triglycerides. Atherosclerosis 2014, 237, 645-651. [CrossRef] [PubMed]

72. Olszanecka, A.; Dragan, A.; Kawecka-Jaszcz, K.; Fedak, D.; Czarnecka, D. Relationships of insulin-like growth factor-1, its binding proteins, and cardiometabolic risk in hypertensive perimenopausal women. Metabolism 2017, 69, 96-106. [CrossRef] [PubMed]

73. Pouriamehr, S.; Barmaki, H.; Rastegary, M.; Lotfi, F.; Afjadi, M.N. Investigation of insulin-like growth factors/insulin-like growth factor binding proteins regulation in metabolic syndrome patients. BMC Res. Notes 2019, 12, 653. [CrossRef] [PubMed]

74. Shah, R.V.; Hwang, S.-J.; Yeri, A.; Tanriverdi, K.; Pico, A.R.; Yao, C.; Murthy, V.L.; Ho, J.; Vitseva, O.; Demarco, D.; et al. Proteins Altered by Surgical Weight Loss Highlight Biomarkers of Insulin Resistance in the Community. Arter. Thromb. Vasc. Biol. 2019, 39, 107-115. [CrossRef]

75. Sekimoto, H.; Boney, C.M. C-Terminal Src Kinase (CSK) Modulates Insulin-Like Growth Factor-I Signaling through Src in 3T3-L1 Differentiation. Endocrinology 2003, 144, 2546-2552. [CrossRef]

76. Volloch, V.; Olsen, B.R. Why cellular stress suppresses adipogenesis in skeletal tissue, but is ineffective in adipose tissue: Control of mesenchymal cell differentiation via integrin binding sites in extracellular matrices. Matrix Biol. 2013, 32, 365-371. [CrossRef]

77. Morandi, E.M.; Verstappen, R.; Zwierzina, M.E.; Geley, S.; Pierer, G.; Ploner, C. ITGAV and ITGA5 diversely regulate proliferation and adipogenic differentiation of human adipose derived stem cells. Sci. Rep. 2016, 6, 28889. [CrossRef]

78. Pucilowska, J.B.; Davenport, M.L.; Kabir, I.; Clemmons, D.R.; Thissen, J.P.; Butler, T.; E Underwood, L. The effect of dietary protein supplementation on insulin-like growth factors (IGFs) and IGF-binding proteins in children with shigellosis. J. Clin. Endocrinol. Metab. 1993, 77, 1516-1521. [CrossRef]

79. Fouque, D.; Le Bouc, Y.; Laville, M.; Combarnous, F.; O Joly, M.; Raton, P.; Zech, P. Insulin-like growth factor-1 and its binding proteins during a low-protein diet in chronic renal failure. J. Am. Soc. Nephrol. 1995, 6, 1427-1433.

80. Vrieling, A.; Voskuil, D.W.; Bonfrer, J.M.; Korse, C.M.; Van Doorn, J.; Cats, A.; Depla, A.C.; Timmer, R.; Witteman, B.J.; E Van Leeuwen, F.; et al. Lycopene supplementation elevates circulating insulin-like growth factor binding protein-1 and -2 concentrations in persons at greater risk of colorectal cancer. Am. J. Clin. Nutr. 2007, 86, 1456-1462. [CrossRef]

81. Crowe, F.L.; Key, T.J.; Allen, N.E.; Appleby, P.N.; Roddam, A.; Overvad, K.; Grønbaek, H.; Tjønneland, A.; Halkjaer, J.; Dossus, L.; et al. The Association between Diet and Serum Concentrations of IGF-I, IGFBP-1, IGFBP-2, and IGFBP-3 in the European Prospective Investigation into Cancer and Nutrition. Cancer Epidemiol. Biomark. Prev. 2009, 18, 1333-1340. [CrossRef] [PubMed]

82. Young, N.J.; Metcalfe, C.; Gunnell, D.; Rowlands, M.-A.; Lane, J.A.; Gilbert, R.; Avery, K.N.L.; Davis, M.; Neal, D.E.; Hamdy, F.C.; et al. A cross-sectional analysis of the association between diet and insulin-like growth factor (IGF)-I, IGF-II, IGF-binding protein (IGFBP)-2, and IGFBP-3 in men in the United Kingdom. Cancer Causes Control. 2012, 23, 907-917. [CrossRef] [PubMed]

83. Krupp, D.; Remer, T.; Penczynski, K.J.; Bolzenius, K.; Wudy, S.A.; Buyken, A.E. Relevance of fruits, vegetables and flavonoids from fruits and vegetables during early life, mid-childhood and adolescence for levels of insulin-like growth factor (IGF-1) and its binding proteins IGFBP-2 and IGFBP-3 in young adulthood. Br. J. Nutr. 2015, 115, 527-537. [CrossRef] [PubMed]

84. Al-Daghri, N.M.; Manousopoulou, A.; Alokail, M.S.; Yakout, S.; Alenad, A.; Garay-Baquero, D.J.; Fotopoulos, M.; Teng, J.; Al-Attas, O.; Al-Saleh, Y.; et al. Sex-specific correlation of IGFBP-2 and IGFBP-3 with vitamin D status in adults with obesity: A cross-sectional serum proteomics study. Nutr. Diabetes 2018, 8, 54. [CrossRef]

85. Boisclair, Y.R.; Yang, Y.W.; Stewart, J.M.; Rechler, M.M. Insulin-like growth factor-I and insulin stimulate the synthesis of IGF-binding protein-2 in a human embryonic kidney cell line. Growth Regul. 1994, 4, 136-146.

86. Bostedt, K.T.; Schmid, C.; Ghirlanda-Keller, C.; Olie, R.; Winterhalter, K.H.; Zapf, J. Insulin-like Growth Factor (IGF) I DownRegulates Type 1 IGF Receptor (IGF 1R) and Reduces the IGF I Response in A549 Non-Small-Cell Lung Cancer and Saos-2/B-10 Osteoblastic Osteosarcoma Cells. Exp. Cell Res. 2001, 271, 368-377. [CrossRef]

87. Thrailkill, K. Dual Hormonal Replacement Therapy with Insulin and Recombinant Human Insulin-Like Growth Factor (IGF)-I in Insulin-Dependent Diabetes Mellitus: Effects on the Growth Hormone/IGF/IGF-Binding Protein System. J. Clin. Endocrinol. Metab. 1997, 82, 1181-1187. [CrossRef]

88. Wolf, E.; Krämer, R.; Blum, W.F.; Föll, J.; Brem, G. Consequences of postnatally elevated insulin-like growth factor-II in transgenic mice: Endocrine changes and effects on body and organ growth. Endocrinology 1994, 135, 1877-1886. [CrossRef]

89. Blum, W.F.; Horn, N.; Kratzsch, J.; O Jørgensen, J.; Juul, A.; Teale, D.; Mohnike, K.; Ranke, M.B. Clinical studies of IGFBP-2 by radioimmunoassay. Growth Regul. 1993, 3, 100-104.

90. Elmlinger, M.W.; Bell, M.; Schüett, B.S.; Langkamp, M.; Kutoh, E.; Ranke, M.B. Transactivation of the IGFBP-2 promoter in human tumor cell lines. Mol. Cell. Endocrinol. 2001, 175, 211-218. [CrossRef]

91. Berg, U.; Enqvist, J.K.; Mattsson, C.M.; Carlsson-Skwirut, C.; Sundberg, C.J.; Ekblom, B.; Bang, P. Lack of sex differences in the IGF-IGFBP response to ultra endurance exercise. Scand. J. Med. Sci. Sports 2008, 18, 706-714. [CrossRef] [PubMed]

92. Gregory, S.M.; Spiering, B.A.; Alemany, J.A.; Tuckow, A.P.; Rarick, K.R.; Staab, J.S.; Hatfield, D.L.; Kraemer, W.J.; Maresh, C.M.; Nindl, B.C. Exercise-Induced Insulin-Like Growth Factor I System Concentrations after Training in Women. Med. Sci. Sports Exerc. 2013, 45, 420-428. [CrossRef] [PubMed] 
93. Allen, N.E.; Appleby, P.N.; Davey, G.K.; Kaaks, R.; Rinaldi, S.; Key, T.J. The associations of diet with serum insulin-like growth factor I and its main binding proteins in 292 women meat-eaters, vegetarians, and vegans. Cancer Epidemiol. Biomarkers Prev. 2002, 11, 1441-1448. [PubMed]

94. Espelund, U.; Bruun, J.M.; Richelsen, B.; Flyvbjerg, A.; Frystyk, J. Pro- and mature IGF-II during diet-induced weight loss in obese subjects. Eur. J. Endocrinol. 2005, 153, 861-869. [CrossRef]

95. Touskova, V.; Trachta, P.; Kavalkova, P.; Drapalova, J.; Haluzikova, D.; Mraz, M.; Lacinova, Z.; Marek, J.; Haluzík, M. Serum concentrations and tissue expression of components of insulin-like growth factor-axis in females with type 2 diabetes mellitus and obesity: The influence of very-low-calorie diet. Mol. Cell. Endocrinol. 2012, 361, 172-178. [CrossRef]

96. Carter, S.; Lemieux, I.; Li, Z.; Alméras, N.; Tremblay, A.; Bergeron, J.; Poirier, P.; Després, J.-P.; Picard, F. Changes in IGFBP-2 levels following a one-year lifestyle modification program are independently related to improvements in plasma apo B and LDL apo B levels. Atherosclerosis 2019, 281, 89-97. [CrossRef]

97. Kopple, J.D.; Cohen, A.H.; Wang, H.; Qing, D.; Tang, Z.; Fournier, M.; Lewis, M.; Casaburi, R.; Storer, T. Effect of Exercise on mRNA Levels for Growth Factors in Skeletal Muscle of Hemodialysis Patients. J. Ren. Nutr. 2006, 16, 312-324. [CrossRef]

98. Takeo, C.; Ikeda, K.; Horie-Inoue, K.; Inoue, S. Identification of Igf2, Igfbp2 and Enpp2 as Estrogen-Responsive Genes in Rat Hippocampus. Endocr. J. 2009, 56, 113-120. [CrossRef]

99. Foster, E.B.; Fisher, G.; Sartin, J.L.; Elsasser, T.H.; Wu, G.; Cowan, W.; Pascoe, D.D. Acute regulation of IGF-I by alterations in post-exercise macronutrients. Amino Acids 2012, 42, 1405-1416. [CrossRef]

100. Nindl, B.C.; Alemany, J.A.; Rarick, K.R.; Eagle, S.R.; Darnell, M.E.; Allison, K.F.; A Harman, E. Differential basal and exerciseinduced IGF-I system responses to resistance vs. calisthenic-based military readiness training programs. Growth Horm. IGF Res. 2017, 32, 33-40. [CrossRef]

101. Mirna, M.; Lichtenauer, M.; Wernly, B.; Paar, V.; Jung, C.; Kretzschmar, D.; Uhlemann, M.; Franz, M.; Hoppe, U.C.; Schulze, P.C.; et al. Novel cardiovascular biomarkers in patients with cardiovascular diseases undergoing intensive physical exercise. Panminerva Med. 2020, 62, 135-142. [CrossRef] [PubMed]

102. Chiba, T.; Yokosuka, O.; Fukai, K.; Hirasawa, Y.; Tada, M.; Mikata, R.; Imazeki, F.; Taniguchi, H.; Iwama, A.; Miyazaki, M.; et al. Identification and investigation of methylated genes in hepatoma. Eur. J. Cancer 2005, 41, 1185-1194. [CrossRef] [PubMed]

103. Zheng, S.; Houseman, E.A.; Morrison, Z.; Wrensch, M.R.; Patoka, J.S.; Ramos, C.; Haas-Kogan, D.A.; McBride, S.; Marsit, C.; Christensen, B.C.; et al. DNA hypermethylation profiles associated with glioma subtypes and EZH2 and IGFBP2 mRNA expression. Neuro-Oncology 2011, 13, 280-289. [CrossRef] [PubMed]

104. Ahrens, M.; Ammerpohl, O.; Von Schönfels, W.; Kolarova, J.; Bens, S.; Itzel, T.; Teufel, A.; Herrmann, A.; Brosch, M.; Hinrichsen, H.; et al. DNA Methylation Analysis in Nonalcoholic Fatty Liver Disease Suggests Distinct Disease-Specific and Remodeling Signatures after Bariatric Surgery. Cell Metab. 2013, 18, 296-302. [CrossRef] [PubMed]

105. Nawathe, A.; Christian, M.; Kim, S.H.; Johnson, M.R.; Savvidou, M.D.; Terzidou, V. Insulin-like growth factor axis in pregnancies affected by fetal growth disorders. Clin. Epigenetics 2016, 8, 11. [CrossRef] [PubMed]

106. Tang, Z.; Gillatt, D.; Rowe, E.; Koupparis, A.; Holly, J.M.; Perks, C.M. IGFBP-2 acts as a tumour suppressor and plays a role in determining chemosensitivity in bladder cancer cells. Oncotarget 2019, 10, 7043-7057. [CrossRef]

107. Biernacka, K.M.; Uzoh, C.C.; Zeng, L.; Persad, R.A.; Bahl, A.; Gillatt, D.; Perks, C.M.; Holly, J.M.P. Hyperglycaemia-induced chemoresistance of prostate cancer cells due to IGFBP2. Endocr. Relat. Cancer 2013, 20, 741-751. [CrossRef]

108. Pickard, A.; McDade, S.S.; McFarland, M.; McCluggage, W.G.; Wheeler, C.M.; McCance, D.J. HPV16 Down-Regulates the Insulin-Like Growth Factor Binding Protein 2 to Promote Epithelial Invasion in Organotypic Cultures. PLoS Pathog. 2015, 11, e1004988. [CrossRef]

109. Phillips, L.M.; Zhou, X.; Cogdell, D.E.; Chua, C.Y.; Huisinga, A.; Hess, K.R.; Fuller, G.N.; Zhang, W. Glioma progression is mediated by an addiction to aberrant IGFBP2 expression and can be blocked using anti-IGFBP2 strategies. J. Pathol. 2016, 239, 355-364. [CrossRef]

110. Kumarasinghe, I.R.; Woster, P.M. Cyclic peptide inhibitors of lysine-specific demethylase 1 with improved potency identified by alanine scanning mutagenesis. Eur. J. Med. Chem. 2018, 148, 210-220. [CrossRef]

111. Strub, T.; Ghiraldini, F.G.; Carcamo, S.; Li, M.; Wroblewska, A.; Singh, R.; Goldberg, M.S.; Hasson, D.; Wang, Z.; Gallagher, S.J.; et al. SIRT6 haploinsufficiency induces BRAFV600E melanoma cell resistance to MAPK inhibitors via IGF signalling. Nat. Commun. 2018, 9, 1-13. [CrossRef] [PubMed] 